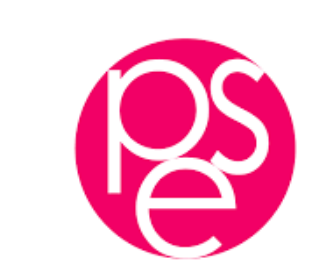

PARISSCHOOL OF ECONOMICS
ECOLE D'ECONOMIE DE PARIS

WORKING PAPER Nº 2020 - 57

Party Preference Representation

\author{
André Blais \\ Eric Guntermann \\ Vincent Arel-Bundock \\ Ruth Dassonneville \\ Jean-François Laslier \\ Gabrielle Péloquin-Skulski
}

JEL Codes:

Keywords: party preference representation, party like/dislike, elections, cabinet, legislature

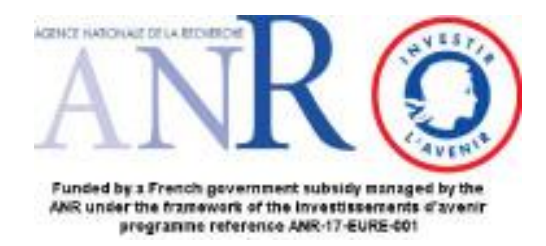




\title{
Party Preference Representation
}

\author{
André Blais, Eric Guntermann, Vincent Arel-Bundock, Ruth Dassonneville, \\ Jean-François Laslier, and Gabrielle Péloquin-Skulski ${ }^{1}$
}

August 2020

\begin{abstract}
Political parties are key actors in electoral democracies: they organize the legislature, form governments, and citizens choose their representatives by voting for them. How citizens evaluate political parties and how well the parties that citizens evaluate positively perform thus provide useful tools to estimate the quality of representation from the individual's perspective. We propose a measure that can be used to assess party preference representation at both the individual and aggregate levels, both in government and in parliament. We calculate the measure for over 160,000 survey respondents following 111 legislative elections held in 38 countries. We find little evidence that the party preferences of different socio-economic groups are systematically over or underrepresented. However, we show that citizens on the right tend to have higher representation scores than their left-wing counterparts. We also find that whereas proportional systems do not produce higher levels of representation on average, they reduce variance in representation across citizens.
\end{abstract}

Keywords: party preference representation, party like/dislike, elections, cabinet, legislature.

\footnotetext{
${ }^{1}$ This is the final draft of an article accepted in Party Politics, please cite the published version when available. Arel-Bundock, Blais, Dassonneville and Péloquin-Skulski: Université de Montréal, Montréal, Canada ; Guntermann : UC Berkeley, USA ; Laslier CNRS-Paris School of Economics, Paris, France.
} 
Elections offer citizens the opportunity to express their views about the issues of the day, the parties and the candidates. The hope is that the candidates and parties, in order to maximize their chances of being elected, will take issue positions that reflect the public's preferences, and that as a consequence there will be strong correspondence between public opinion and the decisions made by legislators and government (Downs 1957). This is what electoral democracy is supposed to achieve (Powell 2000).

Whether that goal is achieved or not is therefore a key question which, for good reasons, has been the object of much work in political science. Many empirical studies have examined the correspondence between the public's policy preferences and the actual policies enacted by governments (Erickson, Mackuen and Stimson 2002; Hobolt and Klemmensen 2005, 2008; Soroka and Wlezien 2010). Other studies have ascertained the degree of congruence in the ideological orientations of the mass public on the one hand and legislators and governments on the other (e.g. Golder and Ferland 2018; Golder and Lloyd 2014; Golder and Stramski 2010; Huber and Powell 1994). All these studies focus on substantive representation, but the literature is not limited to work that considers the interests and preferences of citizens. A second and influential perspective has been to examine the issue of descriptive representation (Pitkin 1967; Mansbridge 2003) where the concern is whether the socio-demographic characteristics of legislators mirror those of the electorate. Work in the field of gender and politics, for instance, has shown that such descriptive representation not only has an important symbolic effect (Wolbrecht and Campbell 2017) but can also facilitate the substantive representation of group interests (Clayton and Zetterberg 2018).

In this paper, we study substantive representation, that is, we ascertain the extent to which citizens' preferences are well reflected in the outcome of the election. In doing so, we move away from a focus on policy preferences and ideology and instead assess the correspondence between citizens' party ratings and these parties' presence in the legislature and government. We argue that focusing on parties and their electoral success is meaningful because legislative elections are first and foremost about how many seats the various parties will have in the legislature and which parties will form government. Voters vote mostly for parties, and they are more satisfied when the party they like best is in government (Anderson et al. 2005). We also think that a focus on party preferences is appropriate for a comparative analysis of representation, as we do not have to make any assumptions about similarities in the dimensionality of politics or the salience of policy issues across countries.

We construct measures of party preference representation in 111 legislative elections and find little evidence that our measures vary systematically with age, gender, education, income, or between urban and rural areas. However, we find that right-wing voters are better represented than left-wing voters. Interestingly, proportional representation systems do not seem to produce higher levels of overall representation, but they do lead to less variance in representation across citizens.

The rest of this article proceeds in four steps. First, we motivate our focus on party preferences to gauge representation. Second, we operationalize the concept of "party preference representation". Third, we describe cross-national survey and election results data which can be used to estimate an individual's degree of representation. Finally, we study how the representation of party 
preferences varies across socio-demographic and ideological groups and types of electoral systems. We end with a discussion of the implications of our findings.

\section{Why study party preference representation?}

To capture the quality of representation, scholars generally measure the congruence between citizens' policy preferences, or their ideological orientations, and those of decision-makers. Such work, however, has to make tough decisions about which issues to take into account or which ideological dimensions to consider for measuring congruence. As a result, most previous studies either focus on the correspondence between public opinion and the government's or parliament's position along the left-right dimension (Golder and Lloyd 2014; Golder and Stramski 2010), or they investigate congruence in a specific policy domain, such as welfare spending (Kang and Powell 2010; Hooghe et al. 2019). When studying these questions comparatively, such an approach has two kinds of limitations. First, in many countries, the political space is characterized by more than one dimension (Bakker et al. 2015) and voters care about more than a single left-right dimension (Stecker and Tausendpfund 2016). Second, the meaning of left and right differs between countries (Piurko et al. 2011) and over time (de Vries et al. 2013).

Focusing on party preference representation, in contrast, allows for more flexibility - as voters tend to vote for the parties that they believe best represent their views about the issues of the day, whatever these issues are. Furthermore, voters do not vote only on the basis of their policy preferences, they take into account many other considerations, such as the perceived competence or honesty of the various candidates and parties. At the end of the day, based on all of these considerations, they form overall evaluations of the parties and vote on the basis of these evaluations. ${ }^{2}$ Our assumption, therefore, is that citizens want the parties they like (dislike) to perform well (poorly).

Based on this reasoning, we argue that an individual will feel well (poorly) represented when the parties she likes (dislikes) perform well, that is, when their preferred parties win many seats in the legislature and cabinet. Assuming that is indeed the case, the electoral performance of the parties that a citizen likes is an appropriate indicator of how well her views are represented. More precisely, when the legislature and the government are composed of parties that a voter likes, her views are well represented. On the contrary, when the legislature and government are composed of parties that she dislikes, she is poorly represented. To capture this idea, in the next section, we introduce a measure of citizens' degree of party preference representation associated with the outcome of an election. This measure combines information on election results with data on citizens' evaluations of political parties.

Our approach is in line with that of Blais, Guntermann, and Bodet (2017), who use party ratings as the reference point for assessing the quality of representation in government at the aggregate level, and with that of Guntermann, Dassonneville and Miller (2020) who ascertain the degree of representation of poor and rich citizens based on how these two groups like parties in government relative to parties in opposition. What is novel is that we propose a measure that can

\footnotetext{
${ }^{2}$ They may also have strategic considerations. This is why we use party ratings rather than vote choice as the reference point since they more directly reflect citizens' preferences.
} 
be used to assess representation in both parliament and government, at both the individual and aggregate level.

\section{Groups, institutions, and representation}

In addition to introducing a measure of party preference representation, we examine descriptively whether some groups are better represented (in terms of party preferences) and whether some institutions foster better representation. In doing so, we focus on three dimensions: socio-demographic characteristics, ideology, and electoral systems.

Whether some groups such as women, the poor, youth, the less educated, or those living in rural areas, are less well represented than others is a perennial issue that is debated by scholars, the media and the larger public. The debate here is three-fold. First, there is the issue of descriptive representation, dealing with the question whether specific groups are over or underrepresented in parliament or cabinet. Second, there is the issue of substantive representation, that is concerned with whether the interests of some groups are better reflected in the composition of parliament or cabinet or its decisions. Third, there is the question how much substantive representation depends on descriptive representation. In this study we are concerned with the substantive representation of groups that prior research has shown to be disadvantaged in terms of descriptive representation, such as the young, women, and the poor.

At the institutional level, previous work primarily focuses on the contrast between proportional and majoritarian systems. As Powell (2000) has elegantly argued, these two electoral systems correspond to two visions of democracy. The majoritarian vision insists on voters' ability to pass reward/punish judgments about the performance of the governing party as the main mechanism through which the political elite is induced to pay attention to public opinion. In contrast, the proportional vision puts the emphasis on the importance of bringing all segments of the population into the policy-making arena. The proportional vision stresses the need to find compromises that will satisfy as many people as possible. There is a huge literature arguing that proportional representation fosters better representation (Lijphart 1999; Powell 2000), that the two systems perform equally (Blais and Bodet 2006; Golder and Lloyd 2014) or that they perform best on different measures of representation (Blais, Guntermann, and Bodet 2017).

Finally, as we are dealing with party preference representation, it makes sense to wonder whether some parties and their supporters are better represented than others. Parties can be distinguished on the basis of many different criteria, but the most salient and common cleavage is that between right-wing and leftist parties (Dalton, Farrell and McAllister, 2011). A point of discussion in the literature on the link between ideology and representation is whether right-wing supporters are better represented than those on the left, and also, as suggested by Iversen and Soskice (2006), whether the right is better represented under a majoritarian system and the left under proportional representation. 


\section{Measuring party preference representation}

Our operationalization of party preference representation considers two pieces of information: election outcomes and citizens' party preferences. First, the outcome of the election can be captured through information on the seat shares that different parties obtain in the legislature or by their presence in government. Second, individuals have sets of party preferences, with varying intensities. ${ }^{3}$ By combining these two pieces of information, we wish to obtain an estimate of how well an individual's preferences are represented. The basic idea is that an individual's degree of representation is highest (lowest) when the parties she likes the most perform well (poorly), that is, they get many (few) seats in the legislature and cabinet.

Our approach is similar to that adopted by Hajnal (2009) in his analysis of the degree of representation of African Americans in U.S. elections. As an indicator of representation Hajnal takes the proportion of voters in a given socio-demographic group that is on the winning side in the election. The underlying logic is simple: "how often a group wins or loses seems to provide a telling account of democratic outcomes." (Hajnal 2009, 41). We focus on the outcomes of elections as well. To be clear, our approach differs from that of Hajnal. We consider the performance of the party one supports rather than that of the individual candidate one voted for, and we have measures of party preference rather than vote to take into account strategic considerations. Still, the basic premise remains the same: a person is better represented when the candidate (party) she votes for (prefers) wins (get many seats in parliament or government).

To construct our measure, we link the individual's ratings of the parties and the results of the election, with a focus on legislative elections. These elections decide how many seats each party has in the legislature and, indirectly, how many seats each party has in government. Hence, the more (fewer) seats the parties that the voter likes (dislikes) have, the greater the representation she derives from the outcome of the election. Like recent studies (Blais, Guntermann, and Bodet 2017; Guntermann, Dassonneville, and Miller 2020), we consider parties' cabinet seat shares. We also consider their seat shares in the legislature, which can also be a means to influence policy (Tsebelis, 2002).

We combine individuals' like/dislike ratings of the parties with the parties' electoral performance to construct our measure of party preference representation. Like Abramson et al. (1992), we normalize ratings at the individual level. For each respondent, the most preferred party (parties) has a score of one and the least preferred party (parties) gets a score of zero. ${ }^{4}$ In doing so, we account for the possibility that some citizens rate all parties more positively (or negatively) than

\footnotetext{
${ }^{3}$ We are agnostic about what makes a person like some parties and dislike others. These preferences can reflect assessments of the parties' policy positions on the major issues of the day, their perceived competence or honesty, evaluations of the party leader or traditional loyalties. Regardless of what causes a voter to like or dislike each party, these ratings indicate her set of preferences among the available options.

${ }^{4}$ We exclude respondents who rated all parties equally. In an alternative version of our measure, we do not normalize preferences to the $[0,1]$ interval, which allows us to keep all respondents. Our substantive results remain similar with this alternative measure.
} 
others. ${ }^{5}$ The overall representation that an individual voter derives from the outcome equals the degree of representation associated with the performance of the various parties. Let $P$ represent the set of parties $p$ for which respondent $i$ can vote, and $L_{i p}$ the rating of $i$ for party $p$. If $S_{p}$ represents the share of seats won by $p,{ }^{6}$ then $i$ 's degree of representation is:

$$
R_{i}=\sum_{p \in P} \frac{L_{i p}-\underline{L}_{i}}{\bar{L}_{i}-\underline{L}_{i}} \cdot S_{p},
$$

where $\bar{L}_{i}$ is a respondent's favorite party's score $\left(\max x_{p \in P}\left(L_{i p}\right)\right)$, and $\underline{L}_{i}$ is the respondent's least favorite party's score $\left(\min _{p \in P}\left(L_{i p}\right)\right)$. We produce an analogous measure of representation using the share of cabinet positions instead of the share of seats in parliament. We thus have two measures of representation: legislative representation and cabinet (government) representation.

To clarify the measure, consider a hypothetical case where there are three parties running in a given election, and where an individual expresses the following ratings: $2,4,6$. Using the above formula, we calculate the rescaled scores as: $0,0.5$, and 1 . If the third party fails to win any seats in the legislature and the first two parties share seats evenly, then that individual's (legislative) party preference representation is equal to 0.25 .

This is the measure that we use in our main analyses. We also perform robustness checks with an alternative unstandardized measure, applying the following formula:

$$
R_{i}=\sum_{p \in P} \frac{L_{i p}}{10} \cdot S_{p},
$$

Party ratings are again normalized from 0 to 1 . However, this measure does not fix the highest rated party rating at 1 or the lowest rated party at 0 . The maximum representation score of 1 is obtained when the individual gives a score of 10 to all the parties that obtain seats and the minimum score of 0 when the individual gives a score of 0 to all the parties that win seats.

\section{Data}

To study individual party preference representation empirically, we use the Integrated Module Dataset (IMD) from the Comparative Study of Electoral System (CSES) project. ${ }^{7}$ Research teams participating in the CSES collaborative research program agree to field a common set of questions in their post-election surveys. The combined dataset of the first four thematic modules of the CSES project - referred to as IMD - includes data from over 50 countries and spans the

\footnotetext{
${ }^{5}$ Those who give systematically high (low) scores may also be signaling that they like (dislike) all the options. This possibility is accounted for with the alternative (unstandardized) measure that is presented below.

${ }^{6}$ We use the share of seats based on the set of parties which a given respondent has rated. If a respondent fails to rate party $\mathrm{A}$, then the seats won by $\mathrm{A}$ are excluded from the total number of seats used to calculate seat shares when we compute our measure for this particular respondent.

${ }^{7}$ The data for seat share in the legislature and cabinet and district magnitude were taken from the individual CSES modules, as these variables are not included in the IMD dataset.
} 
period from 1996 to 2016 . While questions vary somewhat from one module to the next, party like/dislike ratings were included in all four CSES-modules. The exact question wording is the following: "I'd like to know what you think about each of our parties. After I read the name of a political party, please rate it on a scale from 0 to 10 , where 0 means you strongly dislike that party and 10 means that you strongly like that party. If I come to a party you haven't heard of or you feel you do not know enough, just say so." National election teams are invited to ask respondents to rate the six parties that received the most votes, with the possibility, from module 2 onwards, to include up to three additional parties. ${ }^{8}$ These like/dislike ratings provide information about respondents' set of preferences among the various parties. ${ }^{9}$

Taking the IMD dataset, we consider all (lower house) legislative elections in systems in which these influence the composition of government as well as of the legislature. In other words, we focus on parliamentary or premier-presidential systems and therefore exclude all elections held in presidential or president-parliamentary systems (Bormann and Golder 2013; Shugart 2005). We also exclude all elections with a Polity score lower than 6. Data on the distribution of seats in parliament and government come mainly from the CSES. However, for elections in the first module of the CSES and elections where the full seat distribution is not provided, they were complemented with data from Parlgov and the European Journal of Political Research Political Data Yearbook.

It should be noted that we only include the parties for which respondents provided a rating. When no information about a respondent's rating are available for a given party, that party's seats are excluded from the calculation of the seat share. Individuals who did not provide ratings for at least two parties (for whom we do not have relative preferences) or who gave the same score to every party (who are construed to be indifferent) are excluded. Excluding parties with missing values could artificially increase the representation of 'included' parties, assuming that the parties with missing values are unlikely to be preferred. We note, however, that only six parties not included in the 111 elections covered by our study had seats in the legislature.

As a robustness check, we have imputed missing party ratings five times using the "mice" software by Van Buuren and Groothuis-Oudshoorn (2011). With this approach, the party rating of an individual for a given party is imputed based on the party ratings that this same individual has given to the other parties. The results using imputed ratings are reported in Appendix E and not substantively different from those shown in the text.

All in all, our dataset comprises 160,000 individuals and 111 elections held in 38 countries. To

\footnotetext{
${ }^{8}$ There is variation in the timing of these post-election studies, though in general the surveys were fielded immediately following the election. For the observations for which the IMD dataset has information on the timing of the interview, the average number of days between the election and the interview was 50 days, and half of the interviews were done within 23 days from the election. We tested whether representation scores are affected by the timing of the interview. We have thus performed additional estimations which included the number of days between the election and the interview. That variable is not statistically significant, and our results remain unchanged when including this variable.

${ }^{9}$ Our approach is in line with the common approach in the strategic voting literature whereby "each respondent's preferences....is determined by comparing the feeling thermometer scores given to each party." (Abramson et al. 2018, 36-37).
} 
facilitate the interpretation of our results, every variable is rescaled to the [0,1] interval. Histograms for all variables are shown in Appendix B.

The mean representation score derived from the composition of the legislature is .55 and the mean score associated with the composition of the government is .60. In both cases, mean representation is above the midpoint, which is good from a normative point of view and reflects the fact that parties that have higher ratings are over-represented in both the legislature and the executive. Since all the surveys took place after the elections one cannot rule out, however, the possibility that this finding is an artifact of winning the election, that is, that electoral success causes higher ratings rather than higher ratings causing electoral success. The standard deviation of representation derived from the composition of the cabinet is higher (.33) than that associated with the composition of the legislature (.17) since many parties are represented in the latter but not in the former.

Figure 1 presents the distribution of the two representation measures (cabinet and legislature). We can see that the degree of representation derived from the legislative outcome (the right-hand graph) is bell-shaped. Things are different with respect to cabinet derived representation (graph to the left). Indeed, $9 \%$ of the respondents have a score of 0 , which means that the parties that the respondent dislikes the most control the government, while $17 \%$ have a score of 1 , which indicates that the parties that the respondent likes the most hold all cabinet seats. Figure 1 conveys the fact that more people are above the mid-point than under, which stems from the overrepresentation of more popular parties in the legislature and (even more) in cabinet.

Figure 1: Distribution of party preference representation
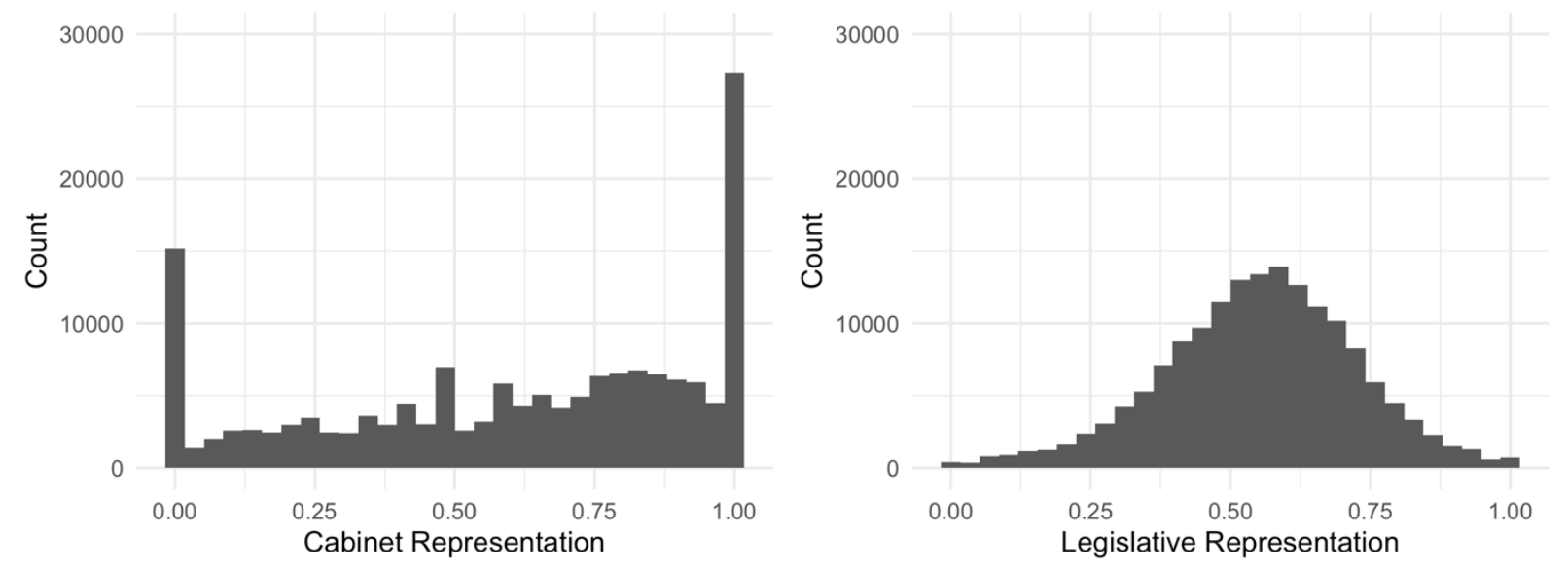

It is important to stress the similarities and differences between our approach and previous ones, specifically those based on policy and ideological congruence. The basic similarity is a correspondence between what people want and what they get. In all cases, citizens' preferences are the reference point. The approaches differ with respect to the type of preference that is considered: policy, ideological, or partisan. Each approach has a different focus, and thus deals with a different outcome: policy decisions, the ideological orientations of legislators or governments, or the partisan composition of legislatures and governments. 
Our approach is close to the ideological congruence perspective in the sense that in both cases citizens' preferences are linked to the outcome of an election. The only difference is that in one case ideology serves as the criterion while it is party preferences in our approach. The case for ideology is that it is a good proxy for the overall orientation of public policies. The problem is that ideological congruence studies are often forced to rely on one specific ideological dimension (left-right) that is less relevant for some people and in some countries. Furthermore, citizens have other types of preferences that are not taken into account in studies of ideological congruence. The case for our approach is that a legislative election is first and foremost about which parties will govern and, as a consequence, party preferences constitute the most meaningful focus when we are considering the outcome of an election.

What about policy congruence? That approach has one great advantage. It compares what people want governments to do with what governments actually do. The outcome is a concrete decision. The major limitation is that it is impossible to analyze all public policies and to distinguish those that are most and least important. Our approach has the advantage of relying on a more global criterion, party preferences, which encompass judgments about whatever policies each individual deems salient, as well as many other considerations, and the disadvantage of being confined to the electoral outcome. With our approach we are ascertaining whether citizens' preferences are well represented on election night, so to speak, and not whether they are reflected in the decisions that are made in the following months and years.

\section{Party preference representation across socio-demographic groups}

Having developed and operationalized a measure of individuals' party preference representation, we can evaluate whether and to what extent that measure is associated with citizens' sociodemographic characteristics. We consider five socio-demographic characteristics: age, gender, education, income, and the rural/urban cleavage. These socio-demographic variables are consistently included in the CSES dataset and they are measured in a standardized way across countries. In addition, each of these variables has previously been found to be politically relevant, and to correlate to voters' choices (see, e.g., the section on sociological approaches in Arzheimer et al.'s [2017] handbook of electoral behavior).

In recent years, a number of studies have considered the extent to which different groups in the population have different levels of influence on government policy (e.g. Bartels 2016; Gilens 2005,2012 ). Such studies have largely focused on the relative influence of different income groups. The approach is a policy congruence one. Gilens, in particular, shows that public policies in the United States better reflect the preferences of the rich than those of the poor. We note, however, that the bias is limited: for instance, the probability that a policy is adopted when $90 \%$ of the rich are in favour of that policy is only $49 \%$, compared to $42 \%$ when $90 \%$ of the poor support it (Gilens 2005, Table 1, page 785). ${ }^{10}$

\footnotetext{
${ }^{10}$ See Branham, Soroka and Wlezien (2017) for a similar argument that inequalities in policy representation are limited.
} 
Our focus is different. Our concern is whether the electoral outcome better reflects the preferences of the rich. It is quite possible that after an election, the rich, being better organized, are more capable of shaping the decisions reached by governments (Leighley and Oser 2018). We assess the correspondence between preferences and electoral outcomes.

The question that we ask is whether the parties that are preferred by one group, such as the rich, perform systematically better in elections than the parties that are preferred by another group, such as the poor. We can see two reasons for such unequal representation. The first is that one group has a higher turnout, and as a consequence the parties it likes performs better. The second is that one group has more money and donates more money to its preferred party, and as a consequence the party it supports spends more and performs better.

Both arguments are not very convincing. It is true that turnout is higher among the rich than among the poor (Leighley and Nagler 2014), though it should be pointed out that turnout is more strongly correlated with age and education than with income (Nevitte et al. 2009). Such reasoning, however, assumes that electoral outcomes would be different if turnout was very high. The studies that have examined that assumption have produced conflicting results. Some studies have shown support for the assumption (Martinez and Gill 2005; Kohler 2011) but many others find no or tiny effects (Highton and Wolfinger 2001; Burnhagen and Marsh 2007; Van der Eijk and van Egmond 2007; Rubenson et al. 2007).

As for the role of money in elections, there is a rich literature which shows that campaign spending has an impact on the vote in American elections, though there may be diminishing returns over a certain level and spending by challengers may matter more than spending by incumbents. The question, however, is whether this systematically advantages one party over another. This is far from clear. Abramowitz's (1989) analysis of campaign spending in U.S. Senate elections shows 'the absence of any clear Republican advantage except among incumbents.' (page 490). Furthermore, 'this advantage has not translated into greater electoral security.' (page 490). There is even greater doubt about the role of money in Europe because of stronger regulation of campaign finance in general and political advertising in particular. Specifically, there are countries where advertising on radio and television is prohibited, others where it hardly exists, and quite a few others where broadcast time cannot be purchased (HoltzBacha and Kaid 2014, pages 558-559).

As a consequence, we expect the socio-demographic bias in party preference representation to remain small, overall.

To verify whether the socio-economic groups that we consider have systematically higher or lower party preference representation scores, in Table 1 we regress individuals' score with respect to the composition of the legislature on five variables: age, gender, education, income, and the urban/rural cleavage. In Table 2, we do the same with the representation scores derived from the composition of the cabinet. We focus on bivariate relationships since our objective is descriptive. The findings, however, are very similar with multivariate estimations, as can be seen in Appendix C. All models include election fixed effects. 
Given the large sample size, we can precisely estimate the coefficients of interest. We therefore focus on the substantive magnitude of the effects. As can be seen from the results in Tables 1 and 2 , neither the legislative representation score nor the cabinet representation score meaningfully varies across socio-demographic groups. Even with a large sample, most of the coefficients are not statistically significant. The largest gap is that associated with income, but even in that case the effect is substantively small. Across all 111 elections covered by our study, the legislative representation score of the richest is a mere .026 higher than that of the poorest (a difference of $5 \%$ relative to the mean); the difference is only slightly higher (.048) for the cabinet representation score. A one standard deviation increase in income is associated with increases of 0.009 and 0.017 standard deviation respectively on the legislature and cabinet representation scores. The effects of age, gender, education and the rural/urban divide are even smaller, and mostly not statistically significant. Electoral outcomes in contemporary democracies are not systematically biased against the partisan preferences of socio-demographic groups.

Table 1: Legislative representation and socio-demographics

\begin{tabular}{lccccc}
\hline \multicolumn{5}{c}{$\mathrm{DV}=$ legislative representation } \\
\hline $\begin{array}{l}\text { Independent } \\
\text { variable }\end{array}$ & Age & Gender & Education & Income & Rural \\
\hline & 0.002 & -0.005 & 0.010 & 0.026 & -0.003 \\
& $(0.007)$ & $(0.002)$ & $(0.004)$ & $(0.004)$ & $(0.003)$ \\
\hline$N$ & 159902 & 160708 & 158578 & 129315 & 140936 \\
$\mathrm{R}^{2}$ & 0.061 & 0.062 & 0.062 & 0.065 & 0.068 \\
\hline
\end{tabular}

Note: All models include election fixed effects (not shown). Standard errors are robust and clustered by election (shown in parentheses).

Table 2: Cabinet representation and socio-demographics

\begin{tabular}{lccccc}
\hline \multicolumn{5}{c}{$\mathrm{DV}=$ legislative representation } \\
\hline $\begin{array}{l}\text { Independent } \\
\text { variable }\end{array}$ & Age & Gender & Education & Income & Rural \\
\hline & 0.011 & -0.007 & 0.011 & 0.048 & -0.012 \\
& $(0.020)$ & $(0.004)$ & $(0.012)$ & $(0.010)$ & $(0.007)$ \\
\hline$N$ & 157431 & 158229 & 156113 & 127135 & 138611 \\
$\mathrm{R}^{2}$ & 0.039 & 0.039 & 0.040 & 0.044 & 0.043 \\
\hline
\end{tabular}

Note: All models include election fixed effects (not shown). Standard errors are robust and clustered by election (shown in parentheses).

Even though we do not find substantial overall differences in citizens' electoral representation scores, this does not mean that there is no meaningful variation in any of the elections. It is possible, for example, that men have a higher score in some elections and a lower score in other cases, implying that these two effects would cancel out in the aggregate. To account for such 
election-specific patterns, we performed similar analyses for each of our five socio-demographic variables in each of the 111 elections. Given the large number of estimations, we adjust for multiple comparisons by using the Holm correction to adjust the p-value in each regression. Appendix D presents the findings for each of our five socio-demographic characteristics and for each of the 111 elections, and with respect to the outcome in both the legislature and cabinet. Of the 1072 coefficients for the socio-demographic variables with the standardized measure that are shown in Appendix D, only 150 are significant. The bottom line is that in a typical election, there is no substantial variation in overall electoral representation score across socio-economic groups.

The findings presented above are based on our main party preference representation measure. All models also exclude respondents who do not rate at least two of the parties or who give the same ratings to all of the parties. In Appendix E, we replicate the main analyses when imputing missing values for party ratings for both the standardized and unstandardized measure of party preference representation. The patterns that emerge from those additional analyses are very similar to those reported here.

\section{Party preference representation and ideology}

In a second step, we look at the role of ideology. This concerns a variable that is known to shape politics and elections in important ways (Dalton, Farrell and McAllister 2011). By focusing on this variable and its connection to party preference representation, we can determine whether people on the left generally derive a higher or lower degree of party preference representation than those on the right. This would occur if there is a systematic tendency for governments and legislatures to be more on one side of the ideological spectrum. Absent such a systematic bias, there should be no difference in representation score between citizens on the left and those on the right.

We also examine whether those with more extremist views derive a lower degree of preference representation. We expect differences between citizens with extreme ideologies and citizens with more moderate ideologies. The former support parties that are less popular than the latter and thus perform poorly in elections, which likely leads them to derive lower representation from electoral outcomes. Furthermore, given that electorally successful extreme parties are often excluded from coalition governments (van Spanje and van der Brug 2007), there might be an additional disadvantage for citizens with extreme preferences when focusing on government composition.

We consider individuals' self-placements on the 0 to 10 left-right scale. The ideology variable is standardized on a 0 to 1 scale (see Appendix A for a description) where 0 means far-left and 1 far-right. Extremism corresponds to the absolute distance between the individual's selfplacement and the mid-point (5) of the scale, also standardized on a 0 to 1 scale, whereby those who place themselves in the centre (5) of the scale have a score of 0 and those who are at the extremes $(0$ or 10$)$ have a score of 1.

Table 3 shows the results of a series of bivariate regression models to explain party preference representation. We also performed multivariate estimations (Appendix C), which produce similar findings. The estimates suggest that citizens who are at the extremes of the left-right scale derive 
lower representation from electoral outcomes. This is the consequence of them being a minority group (there are many more centrists), which leads to their own partisan preferences being more likely to depart from those of their centrist counterparts and thus their preferred parties being weakly represented in the legislature and government. The association between extremism and representation is weak. All in all, the legislative representation score of those at 0 or 10 on the left-right scale is only .056 lower than that of those right in the center (5). Even more surprising is the fact that the impact of extremism is not bigger with respect to the representation score derived from government composition.

Finally, the partisan preferences of those on the right are more strongly reflected in Parliament and government. The impact with respect to the composition of the legislature is modest. An extreme right citizen's representation score is .071 higher than that of an extreme left citizen, and the impact of left-right ideology is greater than that of extremism. The effect is bigger (.199) at the cabinet level. When party preference representation is defined at the level of government, right-wing voters are clearly better represented than those on the left.

Table 3: Representation and political orientations

\begin{tabular}{lcccc}
\hline & \multicolumn{2}{c}{$\begin{array}{c}\text { DV = legislative } \\
\text { representation }\end{array}$} & \multicolumn{2}{c}{$\begin{array}{c}\text { DV = cabinet } \\
\text { representation }\end{array}$} \\
\hline $\begin{array}{l}\text { Independent } \\
\text { variable }\end{array}$ & Extremism & Left-right & Extremism & Left-right \\
\hline & -0.056 & 0.071 & -0.054 & 0.199 \\
& $(0.005)$ & $(0.014)$ & $(0.014)$ & $(0.063)$ \\
\hline$N$ & 135380 & 135380 & 133722 & 133722 \\
$\mathrm{R}^{2}$ & 0.079 & 0.078 & 0.043 & 0.061 \\
\hline Note: All models include election fixed effects (not shown). Standard errors
\end{tabular}
are robust and clustered by election (shown in parentheses).

One reason why those on the right exhibit a greater degree of preference representation is that there are more people on the right than on the left (the parties that are better liked overall are likely to be overrepresented in parliament and even more so in cabinet). Among all respondents in our sample, $40 \%$ have a left-right score greater than .5 while $32 \%$ have a score lower than .5 . However, although we find that there are many elections where people from the right obtain greater representation, there are others where they derive lower representation. In 51 elections those on the right are significantly better off, whereas, for those on the left, this is the case in only 9 elections.

To better understand this pattern, we consider contextual variations in the association between left-right ideology and degree of electoral representation. Although people from the right have a higher representation score overall because they are more numerous, the main factor at play here is clearly the ideological orientation of the government. Put simply, when the government is on the right, right-wing voters derive a higher representation score from the outcome of the election; the opposite holds when there is a leftist government. 
This is shown in the left-hand graph of Figure 2. Here the unit of analysis is the election. There is a very strong correlation (+.84) between the ideology of the government (see Appendix A for a description) and the value of the coefficient associated with voters' ideology (estimated from election-specific regressions linking, in each election, voters' ideology to their party preference representation score). That is, the more right-wing (left-wing) the government, the higher the relative representation of right-wing (left-wing) voters. We should note that when the government is exactly in the centre ( 0.5 on the ideology scale), the predicted coefficient is exactly 0 , that is, there is no gap in the degree of preference representation between those on the left and those on the right. The reason why voters on the right are more often advantaged in our sample is that there are more governments on the right than on the left. More precisely the mean government score in our sample is .55; 63\% of the governments are above 0.5 . And one reason why there are more right-wing governments is that there are more voters on the right than on the left. The right-hand graph of Figure 2 shows the relationship between mean voter ideology and government ideology (here again the unit of analysis is the election). The correlation $(+.38)$ is relatively strong.

We cannot explore in this paper why there are more voters and governments on the right than on the left. We should note, however, that this was not always the case. ${ }^{11}$ Iversen and Soskice's (2006) analysis of government ideology for the 1945/1998 period found about as many left-wing as right-wing governments.

\section{Figure 2. The relationship between Mean Voter Ideology, Government Ideology, and Left-Right Gap in Legislative Representation}
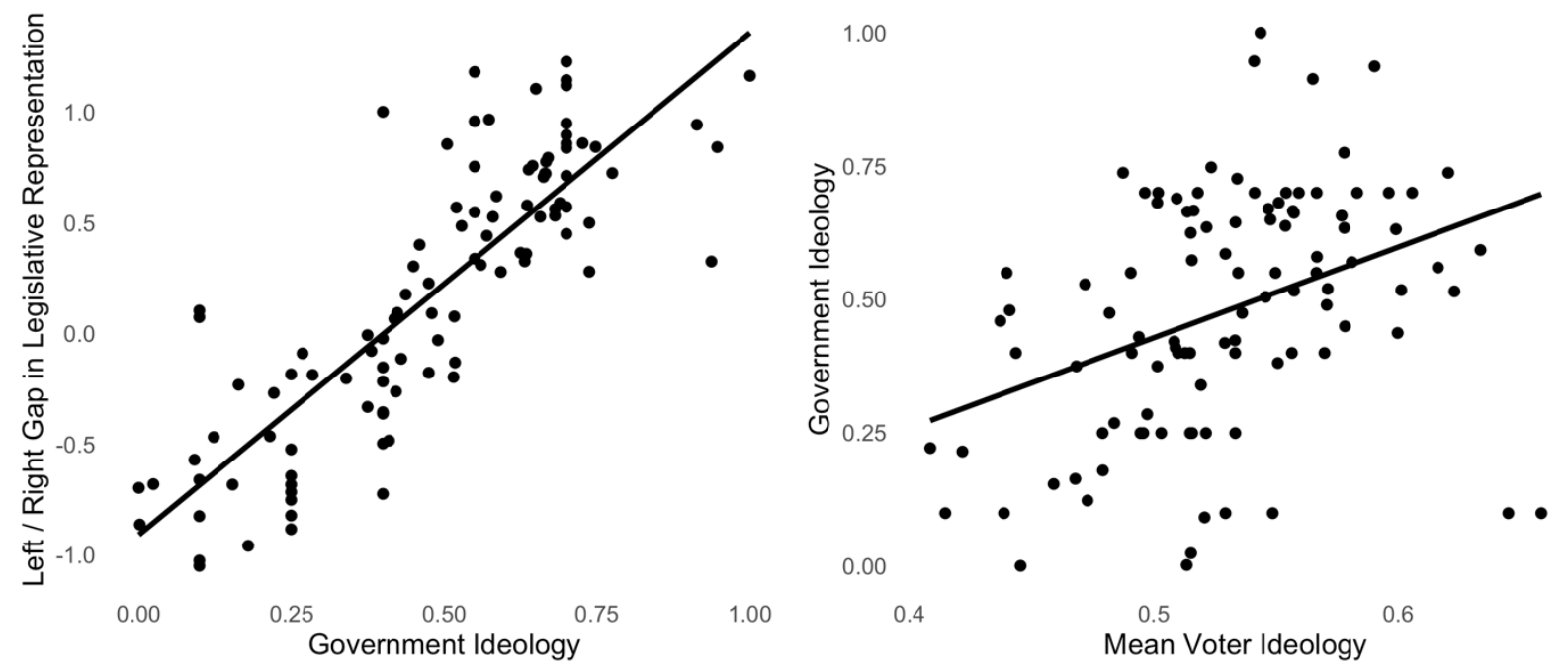

To evaluate the robustness of these results, in Appendix E, we perform the analyses reported in Table 3 when imputing missing values for party ratings with the standardized and unstandardized measures. The patterns are very similar, that is, the impact of extremism is weak or non-

\footnotetext{
${ }^{11}$ Within the period covered by our dataset (1996-2016), there is no evidence that the performance of right-wing parties has improved over time; the mean cabinet ideology score is 0.5 in each of the four modules.
} 
significant while that of ideology is more substantial, especially with respect to cabinet representation.

Whereas we find little systematic variation in the degree of party preference representation across socio-economic groups, we observe that voters on the right derive greater representation most of the time. They do so for the simple reason that there are more right-wing than leftist governments.

\section{Party preference representation and electoral systems}

We finally consider the electoral system. We are interested in the contrast between proportional and non-proportional systems, that we operationalize in different ways (see below). Our prediction is that the mean voter degree of representation is similar in both types of systems. This prediction is inspired by previous research (Blais, Guntermann and Bodet 2017; Golder and Stramski 2010) which has shown little systematic difference between proportional and disproportional systems in terms of overall congruence between citizens and policy makers. However, we expect the distribution of representation scores to be more equal in more proportional systems. The reason is that seat share (in both the legislature and the cabinet) is more concentrated in majoritarian systems where bigger parties are overrepresented in the legislature and where the cabinet is usually a single-party government. As a consequence, majoritarian systems are characterized by a greater contrast between winners and losers (Anderson and Guillory 1997), and therefore between those who have high and low representation scores.

As in prior research (Golder and Stramski 2010; Blais, Guntermann and Bodet 2017), we use three measures of the proportionality of the electoral system: a simple dummy that equals 1 when the electoral formula is proportional, the Gallagher (1991) disproportionality index, and mean district magnitude. For the latter measure, as is usual in the literature, we use a logarithmic transformation of the variable. See Appendix A for more details.

Table 4 shows the relationship between the three indicators of proportionality and our mean representation scores. ${ }^{12}$ Four of the six coefficients are not significant. The mean score is slightly lower in elections held in large districts, but the difference is substantively small. Appendix G presents the scatter plots for the disproportionality index and district magnitude with respect to the cabinet representation score. These scatter plots confirm the absence of any meaningful systematic relationship between electoral systems and the degree of party preference representation. In short, the results in Table 4 offer no evidence that the overall degree of party preference representation varies across electoral systems.

\footnotetext{
${ }^{12}$ Appendix F presents the mean representation score and standard deviation for each individual election.
} 
Table 4. Mean representation and electoral systems

\begin{tabular}{lcccccc}
\hline & \multicolumn{2}{c}{ DV = mean legislative representation } & \multicolumn{2}{c}{ DV mean cabinet representation } \\
\hline $\begin{array}{l}\text { Independent } \\
\text { variable }\end{array}$ & Proportional & $\begin{array}{c}\text { Gallagher } \\
\text { index }\end{array}$ & $\begin{array}{c}\text { District } \\
\text { magnitude }\end{array}$ & Proportional & $\begin{array}{c}\text { Gallagher } \\
\text { index }\end{array}$ & $\begin{array}{c}\text { District } \\
\text { magnitude }\end{array}$ \\
\hline \multirow{3}{*}{ Constant } & -0.021 & 0.004 & -0.052 & -0.018 & 0.007 & -0.074 \\
& $(0.012)$ & $(0.021)$ & $(0.017)$ & $(0.013)$ & $(0.027)$ & $(0.021)$ \\
& 0.562 & 0.544 & 0.563 & 0.616 & 0.599 & 0.628 \\
$N$ & $(0.011)$ & $(0.008)$ & $(0.007)$ & $(0.011)$ & $(0.011)$ & $(0.009)$ \\
$\mathrm{R}^{2}$ & 111 & 110 & 111 & 109 & 108 & 109 \\
\hline
\end{tabular}

Note: Robust standard errors in parentheses.

Even though proportional systems do not produce a higher overall mean representation score, we expect them to reduce individual inequalities between voters. That is, that some citizens have a very high score, while others have a very low score. This should be particularly the case for cabinet representation. The reason is simply that more parties are represented in the cabinet under PR. If there are for instance two parties in a coalition government, many voters may strongly like one party and strongly dislike the other and will end up with a middle of the road score while few will have either a very high or a very low score. This is less likely with singleparty governments that are usually found in majoritarian systems. To verify whether proportional rules are associated with lower inequalities in electoral representation scores, we analyze the correlation between our three measures of electoral systems and the standard deviation of citizens' electoral representation scores in each election. Table 5 provides empirical support for our expectation, which suggests that proportional rules are associated with more equal party preference representation scores. Appendix $\mathrm{H}$ presents the scatter plots for each of these bivariate relationships, which show no evidence of outlier-driven results.

Table 5. The dispersion of representation and electoral systems

\begin{tabular}{lcccccc}
\hline & \multicolumn{2}{c}{ DV = standard deviation of legislative } & \multicolumn{2}{c}{ DV= standard deviation of cabinet } \\
representation & & \multicolumn{3}{c}{ representation } \\
\hline $\begin{array}{l}\text { Independent } \\
\text { variable }\end{array}$ & Proportional & $\begin{array}{c}\text { Gallagher } \\
\text { index }\end{array}$ & $\begin{array}{c}\text { District } \\
\text { magnitude }\end{array}$ & Proportional & $\begin{array}{c}\text { Gallagher } \\
\text { index }\end{array}$ & $\begin{array}{c}\text { District } \\
\text { magnitude }\end{array}$ \\
\hline \multirow{4}{*}{ Constant } & -0.036 & 0.068 & -0.041 & -0.084 & 0.144 & -0.111 \\
& $(0.005)$ & $(0.011)$ & $(0.009)$ & $(0.016)$ & $(0.026)$ & $(0.024)$ \\
& 0.195 & 0.144 & 0.180 & 0.390 & 0.274 & 0.359 \\
$N$ & $(0.005)$ & $(0.005)$ & $(0.004)$ & $(0.014)$ & $(0.011)$ & $(0.010)$ \\
$\mathrm{R}^{2}$ & 111 & 110 & 111 & 109 & 108 & 109 \\
\hline
\end{tabular}

Note: Robust standard errors in parentheses. 
Our findings about the impact of the electoral system are clear. Proportional systems do not enhance the overall degree of party preference representation, but they do reduce differential rates of representation between individuals.

\section{Conclusion}

We have proposed a simple measure of the party preference representation that citizens derive from the outcome of an election. That measure is based on two assumptions. First, elections and voting are first and foremost about parties. Second, citizens 'degree of representation in an election is maximized (minimized) when the parties that they like the most are strongly (weakly) represented in the legislature/cabinet.

We have used the CSES data set and computed electoral outcome representation score for each of the 160,000 individuals in the 111 legislative elections held in non-presidential systems. We find that the representation score associated with the partisan composition of the legislature is slightly above the mid-point and is mostly normally distributed while that associated with the partisan composition of the cabinet has peaks around 0 and 1 and has a relatively high mean, reflecting the fact that the parties that are the most liked are overrepresented in government.

We wished to determine whether some socio-demographic groups systematically obtain higher party preference representation scores from electoral outcomes in contemporary democracies. This does not mean that some of these groups do not exercise more power. It does mean, however, that whatever power differential they may enjoy is not the consequence of electoral outcomes, that is, the parties that these groups prefer do not systematically perform better in elections. That power differential, if it exists, occurs independently of elections.

We also ascertain whether some politically defined groups derive greater representation from the partisan composition of the legislature and cabinet. We expected those with extreme views on the left/right dimension to be disadvantaged because the parties that they prefer tend to be less popular among the whole electorate and are also less likely to be invited to be part of a coalition government. We find some support for that expectation though the pattern is weak.

Finally, we find that citizens on the right have higher representation scores than their left-wing counterparts. This is because there are more right-wing than left-wing voters and governments in contemporary democracies. Why this is the case and whether this pattern is likely to change in the future is beyond the goal of this study.

At the aggregate level, proportional systems do not perform better in terms of overall voter representation, but they do reduce inequalities.

We hope to have convinced readers that our measure, which is based on what we believe to be reasonable assumptions (i.e. elections are first and foremost about parties, and one's degree of representation in an election is maximized when the parties she likes the most have many seats in the legislature and cabinet) is a fruitful one and provides new insights about the meaning of electoral outcomes at both the individual and aggregate level. 
We believe that our measure captures a crucial aspect of representation in an electoral democracy. One is more likely to feel well represented when the party she prefers has many seats in the legislature and cabinet. This is, of course, only one dimension of representation. One is also more likely to feel well represented when the policies she prefers are adopted and implemented by the government. This is policy representation. It is possible to have strong electoral outcome representation and weak policy representation or the reverse. Both types of representation deserve close examination.

\section{References}

Abramowitz, A.I. (1989). Campaign Spending in U.S. Senate Elections. Legislative Studies Quaterly 14 (4): 487-507.

Abramson, P.R., Aldrich, J.H., Paolino, P. \& Rohde, D.H. (1992).'Sophisticated' Voting in the 1988 Presidential Primaries. American Political Science Review 86 (1): $55-69$

Abramson, P.R., Aldrich, J.H., Diskin, A., Houck, A.M, Levine, R., Scotto, T.J. \& Sparks, D.B. (2018). The effect of national and constituency level expectations on tactical voting in the British general election of 2010. In L. B. Stephenson, J. H. Aldrich, \& A. Blais (Eds.), The Many Faces of Strategic Voting: Tactical Behavior in Electoral Systems Around the World (pp. 28-60). Ann Arbor, Michigan: University of Michigan Press.

Anderson, C., Blais, A., Bowler, S., Donovan, T. \& Listhaug, O. (2005). Losers' Consent : Elections and Democratic Legitimacy. Oxford: Oxford University Press.

Anderson, C.J. \& Guillory, C.A. (1997). Political Institutions and Satisfaction with Democracy: A Cross-National Analysis of Consensus and Majoritarian Systems. American Political Science Review 91 (1): 66-81.

Arzheimer, K., Evans, J. \& Lewis-Beck, M.S. (eds.) (2017). The SAGE Handbook of Electoral Behaviour. Thousand Oaks: Sage Publications.

Bakker, R. et al. (2015). Measuring Party Positions in Europe: The Chapel Hill Expert Survey Trend File, 1999-2010. Party Politics 21(1): 143-152.

Blais, A., Guntermann, E. \& Bodet, M. A. (2017). Linking party preferences and the composition of government: A new standard for evaluating the performance of electoral democracy. Political Science Research and Methods 5(2): 315-331.

Blais, A. \& Bodet, M.A. (2006). Does Proportional Representation Foster Closer Congruence Between Citizens and Policymakers? Comparative Political Studies 39: 1243-1262

Bormann, N-C. \& Golder, M. (2013) Democratic Electoral Systems Around the World, 19462011. Electoral Studies 32: 360-369. 
Burnhagen, P. \& Marsh, M. (2007) The partisan effects of low turnout: Analyzing vote abstention as a missing data problem. Electoral Studies 26 (3): 548-560.

Clayton, A. \& Zetterberg, P. (2018). "Quota shocks: Electoral gender quotas and government spending priorities worldwide." The Journal of Politics 80: 916-932.

Dalton, R.J., Farrell, D.M. \& McAllister, I. (2011). Political and Democratic Linkage: How Parties Organize Democracy. Oxford: Oxford University Press.

Dassonneville, R. (forthcoming). Change and Continuity in the Ideological Gender Gap. A Longitudinal Analysis of Left-Right Self-Placement in OECD Countries. European Journal of Political Research. Online first.

De Vries, C.E., Hakhverdian, A. \& Lancee, B. (2013). The Dynamics of Voters' Left/Right Identification: The Role of Economic and Cultural Attitudes. Political Science Research and Methods 1(2): 223-238.

Downs, A. 1957. An Economic Theory of Democracy. New York: Harper and Brothers.

Gallagher, M., 2019. Election indices dataset at

http://www.tcd.ie/Political_Science/people/michael_gallagher/ElSystems/index.php

Gilens, M. (2012) Affluence and Influence: Economic Inequality and Political Power in America. Princeton University Press.

Gilens, M. (2005) Inequality and Democratic Responsiveness. Public Opinion Quarterly 69 (5): 778-796.

Golder, M. \& Ferland, B. (2018). Electoral Rules and Citizen-Elite Ideological Congruence. In: E.S. Herron, R. J. Pekkanen and M.S. Shugart (eds.) The Oxford Handbook of Electoral Systems. Oxford: Oxford University Press (pp. 213-246).

Golder, M. \& Stramski, J. (2010). Ideological Congruence and Electoral Institutions. American Journal of Political Science 54: 90-106

Golder, M. \& Lloyd, G. (2014). Re-evaluating the Relationship between Electoral Rules and Ideological Congruence. European Journal of Political Research 53: 200-212.

Guntermann, E., Dassonneville, R. \& Miller, P. (2020) Are Inequalities in Representation Lower under Compulsory Voting? Policy Studies 41 (2-3): 151-171.

Hanjal, Z.L. (2009). Who loses in American democracy? A count of votes demonstrates the limited representation of African Americans. American Political Science Review 103 (1): 37-57.

Highton, B \& Wolfinger, R. E. (2001) The political implications of higher turnout. British Journal of Political Science 31 (1): 179-192. 
Holtz-Bacha, C \& Kaid, L.L. (2014). Political Advertising in International Comparison. In: H.Cheng (eds.) The Handbook of International Advertising Research. New Jersey: John Wiley \& Sons.

Hooghe, M., Dassonneville, R. \& Oser, J. (2019). Public Opinion, Turnout and Social Policy: A Comparative Analysis of Policy Congruence in European Liberal Democracies. Political Studies 67(4): 992-1009.

Iversen, T. \& Soskice, D. (2006). Electoral institutions and the politics of coalitions: Why some democracies redistribute more than others. American Political Science Review 100(2): 165-181.

Kang, S.-G. \& Powell, G.B.Jr. (2010). Representation and Policy Responsiveness: The Median Voter, Election rules, and Redistributive Welfare Spending. Journal of Politics 72(4): 10141028.

Kohler, U. (2011) Estimating the potential outcome of nonvoter on outcomes of parliamentary elections in proportional systems with an application to German national elections from 1949 to 2009. Electoral Studies 30(3): 497-509.

Leighley, J.E. \& Oser, J. (2018). Representation in an Era of Political Economic Inequality: How and When Citizen Engagement Matters. Perspectives on Politics 16(2): 328-344.

Leighley, J.E \& Nagler, J. (2014). Who Votes Now? Princeton: Princeton University Press.

Lijphart, A. (1999). Patterns of Democracy: Government Forms and Performance in Thirty-Six Contries. New Haven: Yale University Press.

Mansbridge, J. (2003). Rethinking representation. American Political Science Review 97 (4): 515-528.

Martinez, M.D. \& Gill, J. (2005) The Effects of Turnout on Partisan Outcomes in U.S. Presidential Elections 1960-2000. The Journal of Politics 67(4): 1248-1274.

Nevitte, N., Blais, A., Gidengil, E., \& Nadeau, R. (2009) Socioeconomic Status and Nonvoting: A Cross-National Comparative Analysis. In: H-D Klingemann (eds.) The Comparative Study of Electoral Systems. Oxford: Oxford University Press (pp.85-107).

Pitkin, H. (1967). The Concept of Representation. Berkeley: University of California Press.

Piurko, Y., Schwartz, S.H. \& Davidov, E. (2011). Basic Personal Values and the Meaning of Left-Right Political Orientations in 20 Countries. Political Psychology 32(4): 537-561.

Powell, G.B.Jr. (2000). Elections as Instruments of Democracy: Majoritarian and Proportional Visions. New Haven: Yale University Press. 
Rubenson, D., Blais, A., Fournier, F., Gidengil, E. \& Nevitte, N. (2007) Does low turnout matter? Evidence from the 2000 Canadian Federal Election. Electoral Studies 26(3): 589-597.

Shugart, M.S. (2005). Semi-Presidential Systems: Dual Executive And Mixed Authority Patterns. French Politics 3: 323-351.

Stecker, C., \& Tausendpfund, M. (2016). Multidimensional Government-Citizen Congruence and Satisfaction with Democracy. European Journal of Political Research 55(3): 492-511.

Tsebelis, G. (2002). Veto players: How Political Institutions Work. Princeton (NJ): Princeton University Press.

Van Buuren, S. \& Karin Groothuis-Oudshoorn. (2011). mice: Multivariate imputation by chained equations in R. Journal of Statistical Software 45(3): 1-67.

Van der Eijk, C and van Egmond, M. (2007). Political effects of low turnout in national and European elections. Electoral Studies 26(3): 561-573.

Van Spanje, J., \& Van Der Brug, W. (2007). The party as pariah: The exclusion of antiimmigration parties and its effect on their ideological positions. West European Politics 30(5): 1022-1040.

Wolbrecht, C. \& Campbell, D.E. (2017). "Role models revisited: Youth, novelty, and the impact of female candidates." Politics, Groups, and Identities 5: 418-434. 


\section{Appendix A. Question wording and coding}

Age: Continuous measure rescaled from 0 to 1 .

Gender: Based on self-identification. $1=$ woman, $0=$ man.

Education: Reports the respondent's highest level of completed education. The options were "None, Early childhood education, Primary, Lower secondary, Upper secondary, Postsecondary, Short-cycle tertiary, Bachelor or equivalent, Master or equivalent, Doctoral or equivalent." Rescaled from 0 to 1 , where 1 is doctoral or equivalent.

Income: Reports the annual household income quintile in which the respondent's household falls. Rescaled from 0 to 1 , where 1 is the highest household income quintile.

Rural/Urban: Reports the respondent's place of residence. The options are "rural area or village, small or middle-sized town, suburbs of large town or city, large town or city". Rescaled from 0 to 1 , where 0 is large town or city and 1 is rural area or village.

Ideology (individual): Reports the respondent's location on the political spectrum. The question was: "In politics people sometimes talk of left and right. Where would you place yourself on a scale from 0 to 10, where 0 means the left and 10 means the right?" Rescaled from 0 to 1 , where 1 is the right.

Extremism: Extremism is measured based on a survey question asking the respondents to selfdetermine their political ideology on the left-right scale. The question was: "In politics people sometimes talk of left and right. Where would you place yourself on a scale from 0 to 10 , where 0 means the left and 10 means the right?" We use the absolute difference between the voter's position and the center, creating a variable ranging from 0 to 5 . Rescaled from 0 to 1 , where 1 is respondents located at 0 or 10 .

Proportional representation: Reports the electoral system used for each election. Elections are coded as 1 if the electoral system is PR, alternative vote or mixed member proportional and they are coded as 0 if the electoral system is majoritarian or mixed parallel. We use Matt Golder's Democratic Electoral Systems (DES) version 3.0 dataset.

Gallagher index: The data are taken from Michael Gallagher's dataset. For the elections not included in Gallagher's dataset, the index is calculated using the vote share and seat share variables in the CSES dataset. Rescaled from 0 to 1 , where 1 is the most disproportional outcome.

District magnitude: Represents the logarithmic transformation of the district magnitude for each election. The district magnitude is calculated by dividing the total number of seats by the total number of districts in all tiers. Rescaled from 0 to 1 , where 1 is the biggest district magnitude.

Ideology (cabinet): Represents the score of the cabinet on the ideological spectrum. This variable is created using the expert judgement of the parties 'position on a left-right scale included in the 
CSES, and the portfolio share of each party in the cabinet. We multiply the party's portfolio share by its ideology score. We then add the score of each party in a given election. Scaled from 0 to 1 .

Representation score (cabinet): We first determine how much respondents like and dislike a party using the following question: "I'd like to know what you think about each of our parties. After I read the name of a political party, please rate it on a scale from 0 to 10, where 0 means you strongly dislike that party and 10 means that you strongly like that party. If I come to a party you haven't heard of or you feel you do not know enough, just say so.". We normalize party ratings so that the highest rated party is given a score of 1 and the lowest rated party a score of 0 . All the other parties are given a score that equals the original score minus the score of the lowestrated party divided by the difference in the scores of the highest and lowest rated parties. We then multiply this score by the parties 'share of cabinet portfolios and add each party's score for a given election. Scaled from 0 to 1 .

Representation score (legislature): We first determine how much respondents like and dislike a party using the following question: "I'd like to know what you think about each of our parties. After I read the name of a political party, please rate it on a scale from 0 to 10, where 0 means you strongly dislike that party and 10 means that you strongly like that party. If I come to a party you haven't heard of or you feel you do not know enough, just say so.". We normalize party ratings so that the highest rated party is given a score of 1 and the lowest rated party a score of 0 . All the other parties are given a score that equals the original score minus the score of the lowestrated party divided by the difference in the scores of the highest and lowest rated parties. We then multiply this score by the parties 'share of seats in the legislature and add each party's score for a given election. Scaled from 0 to 1.

Absolute Representation score (cabinet): We first determine how much respondents like and dislike a party using the following question: "I'd like to know what you think about each of our parties. After I read the name of a political party, please rate it on a scale from 0 to 10 , where 0 means you strongly dislike that party and 10 means that you strongly like that party. If I come to a party you haven't heard of or you feel you do not know enough, just say so.". We then multiply this score by the parties 'share of cabinet portfolios and add each party's score for a given election. Scaled from 0 to 1.

Absolute Representation score (legislature): We first determine how much respondents like and dislike a party using the following question: "I'd like to know what you think about each of our parties. After I read the name of a political party, please rate it on a scale from 0 to 10 , where 0 means you strongly dislike that party and 10 means that you strongly like that party. If I come to a party you haven't heard of or you feel you do not know enough, just say so.". We then multiply this score by the parties 'share of seats in the legislature and add each party's score for a given election. Scaled from 0 to 1.

Standard deviation of representation score (cabinet): The standard deviation of the representation score (cabinet). 
Standard deviation of representation score (legislature): The standard deviation of the representation score (legislature).

\section{Appendix B. Variable distributions}

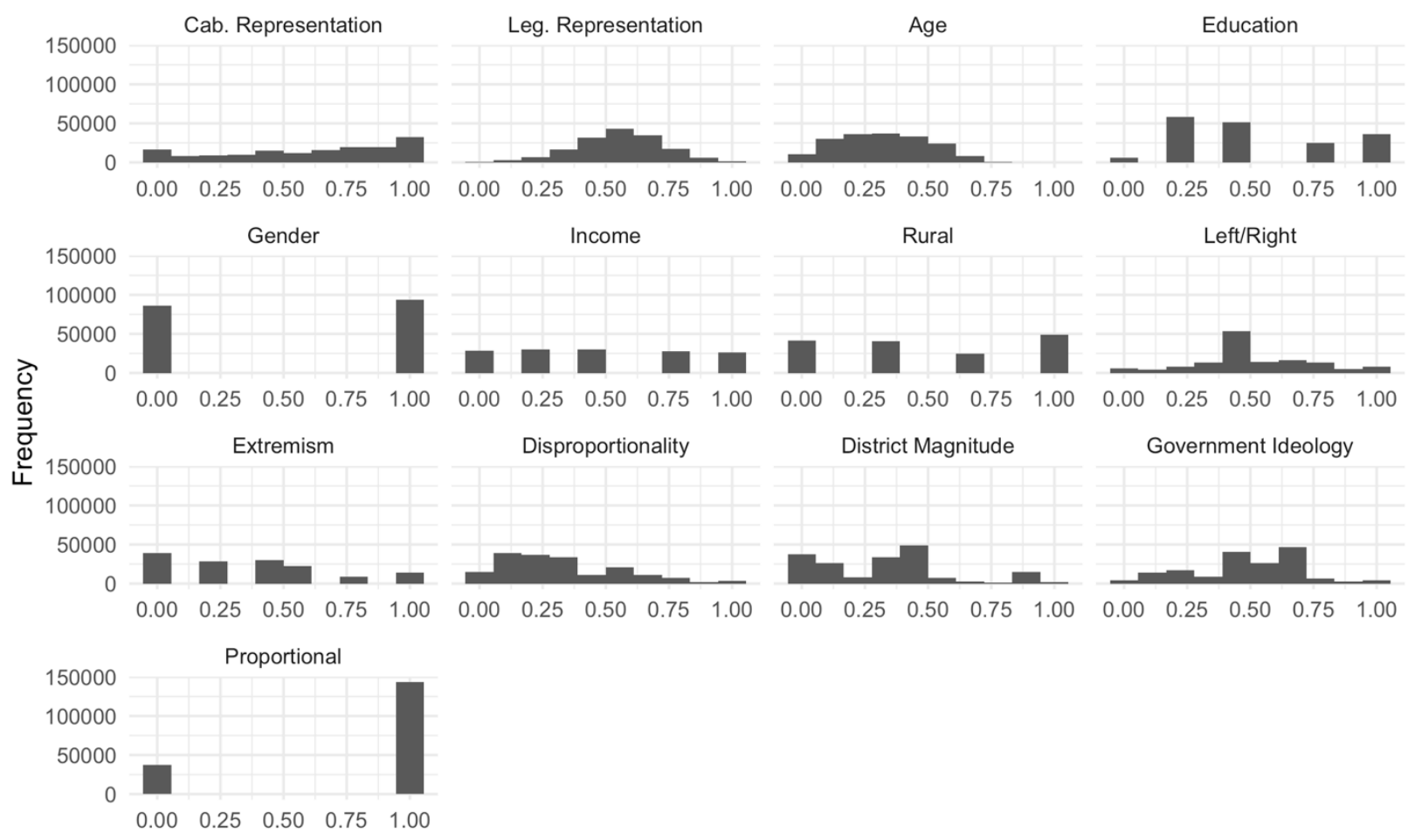




\section{Appendix C. Multivariate analysis of the representation scores}

\begin{tabular}{lcc}
\hline $\begin{array}{l}\text { Independent } \\
\text { variable }\end{array}$ & $\begin{array}{c}\text { DV }=\text { Legislative } \\
\text { representation }\end{array}$ & $\begin{array}{c}\text { DV = Cabinet } \\
\text { representation }\end{array}$ \\
\hline Age & 0.015 & 0.028 \\
Gender & $(0.008)$ & $(0.019)$ \\
& -0.005 & -0.003 \\
Education & $(0.002)$ & $(0.004)$ \\
& 0.004 & 0.006 \\
Extremism & $(0.004)$ & $(0.010)$ \\
& -0.065 & -0.075 \\
Income & $(0.005)$ & $(0.015)$ \\
& 0.022 & 0.043 \\
Left/Right & $(0.003)$ & $(0.008)$ \\
& 0.086 & 0.239 \\
Rural & $(0.015)$ & $(0.066)$ \\
& -0.001 & -0.007 \\
\hline
\end{tabular}

Note: All models include election fixed effects (not shown). Standard errors are robust and clustered by election (shown in parentheses). 


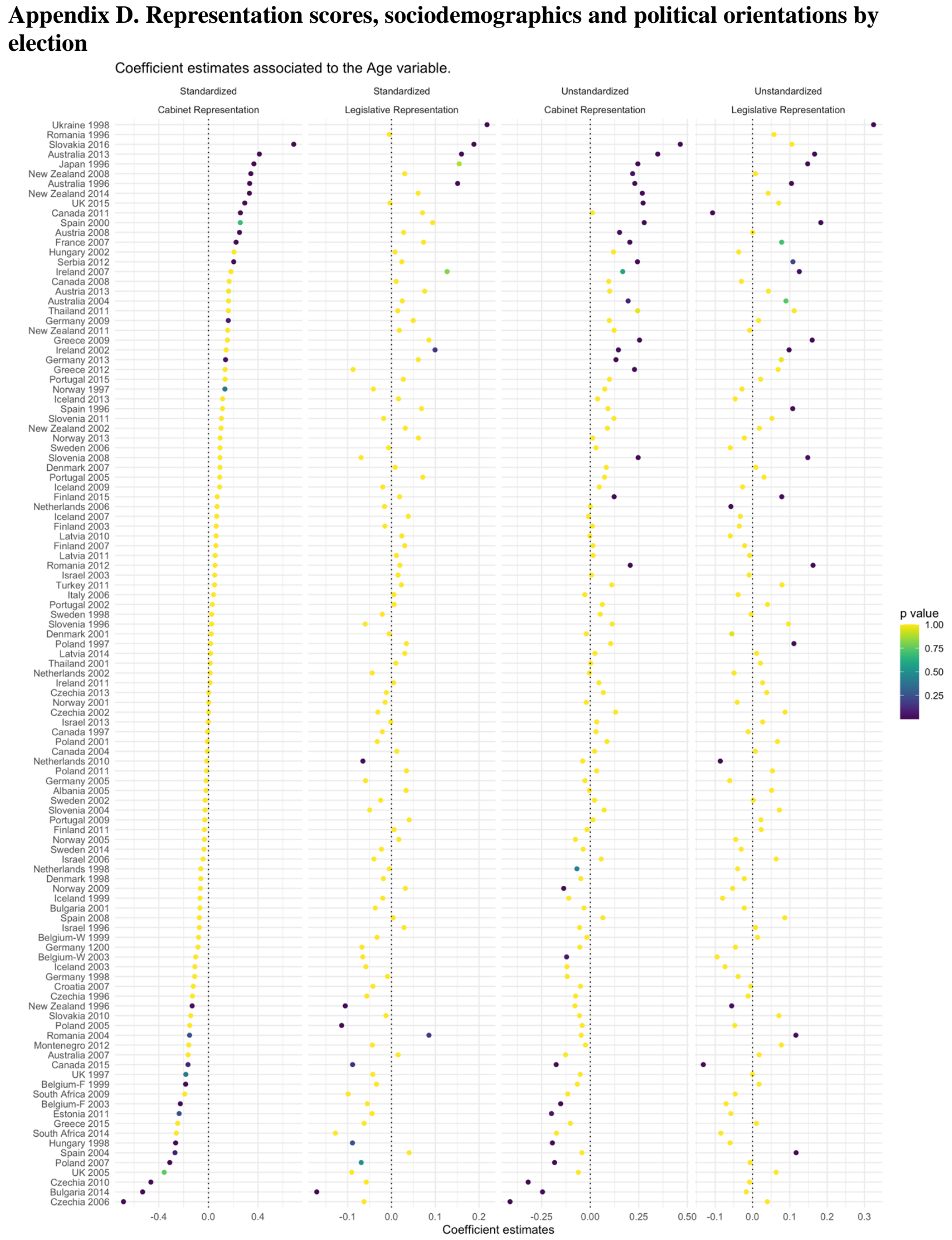


Coefficient estimates associated to the Education variable.

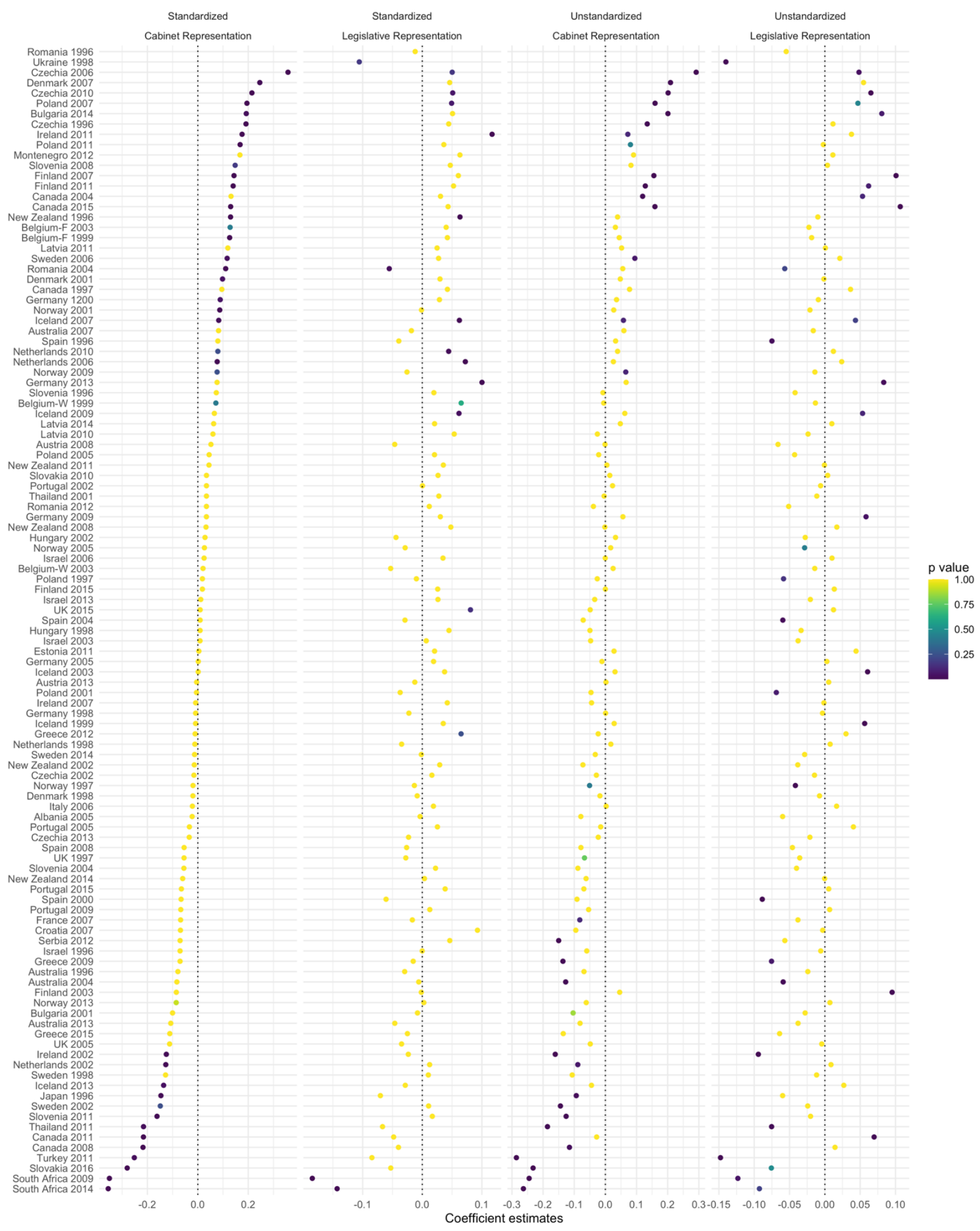


Coefficient estimates associated to the Gender variable.

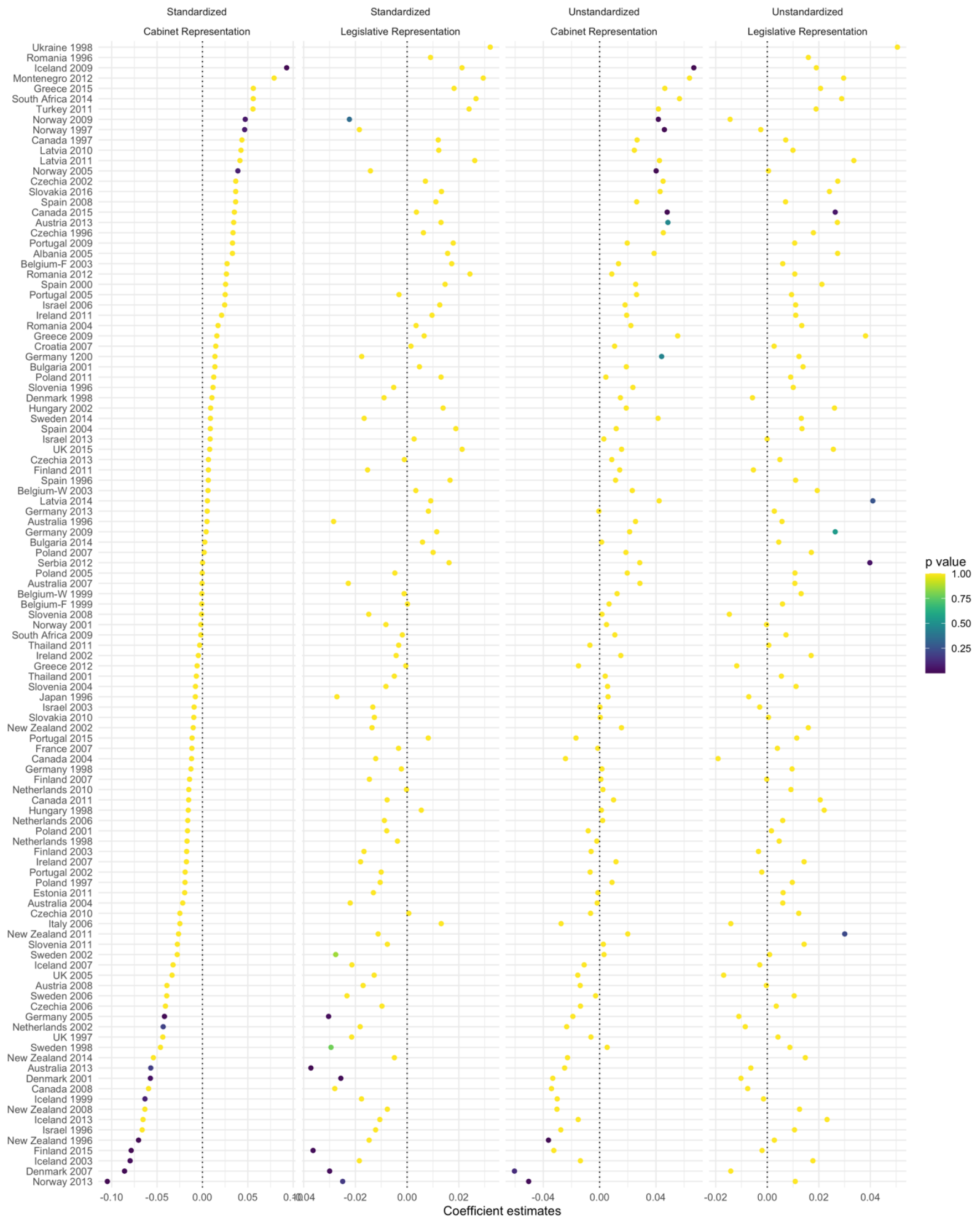


Coefficient estimates associated to the Income variable.

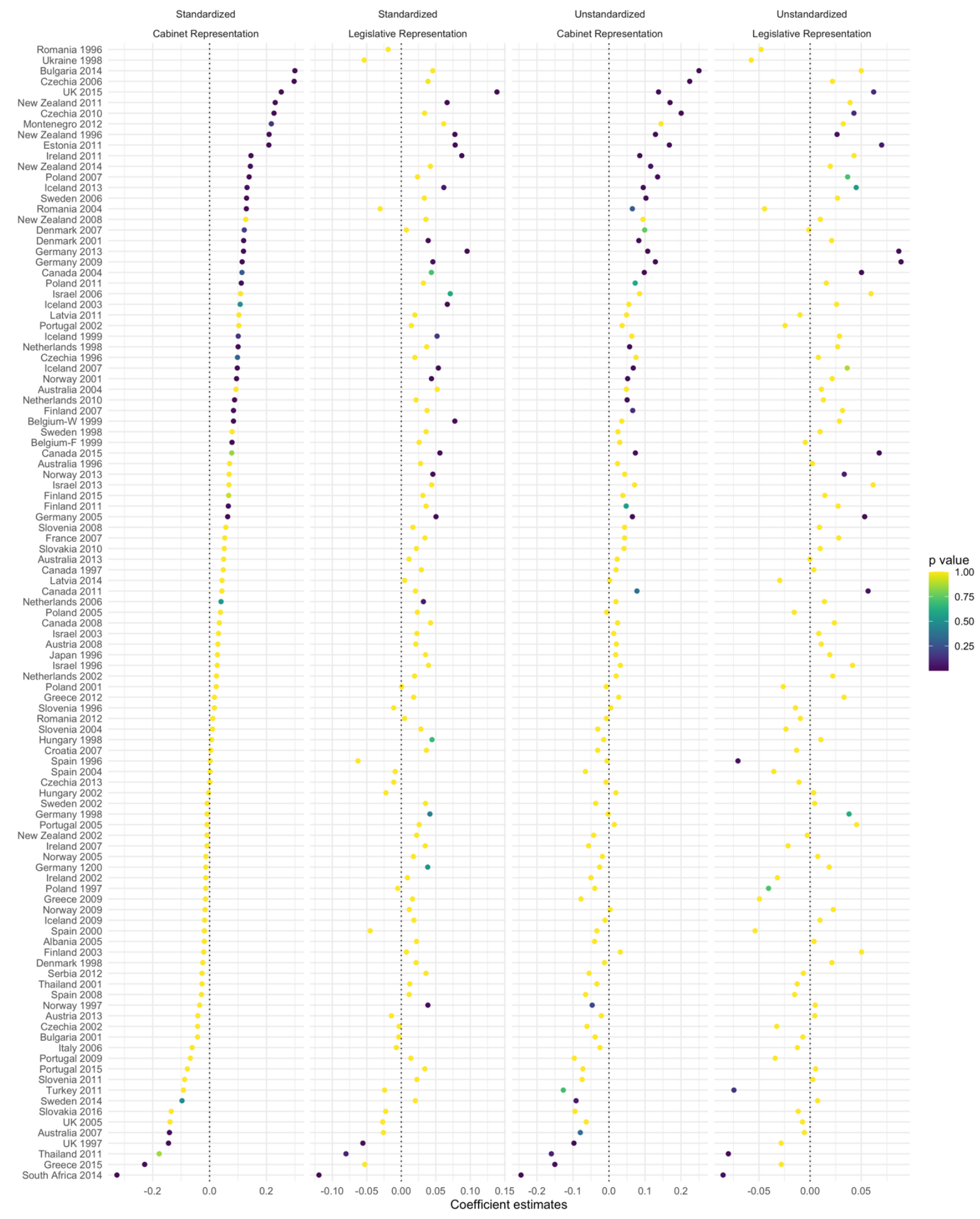


Coefficient estimates associated to the Rural variable.

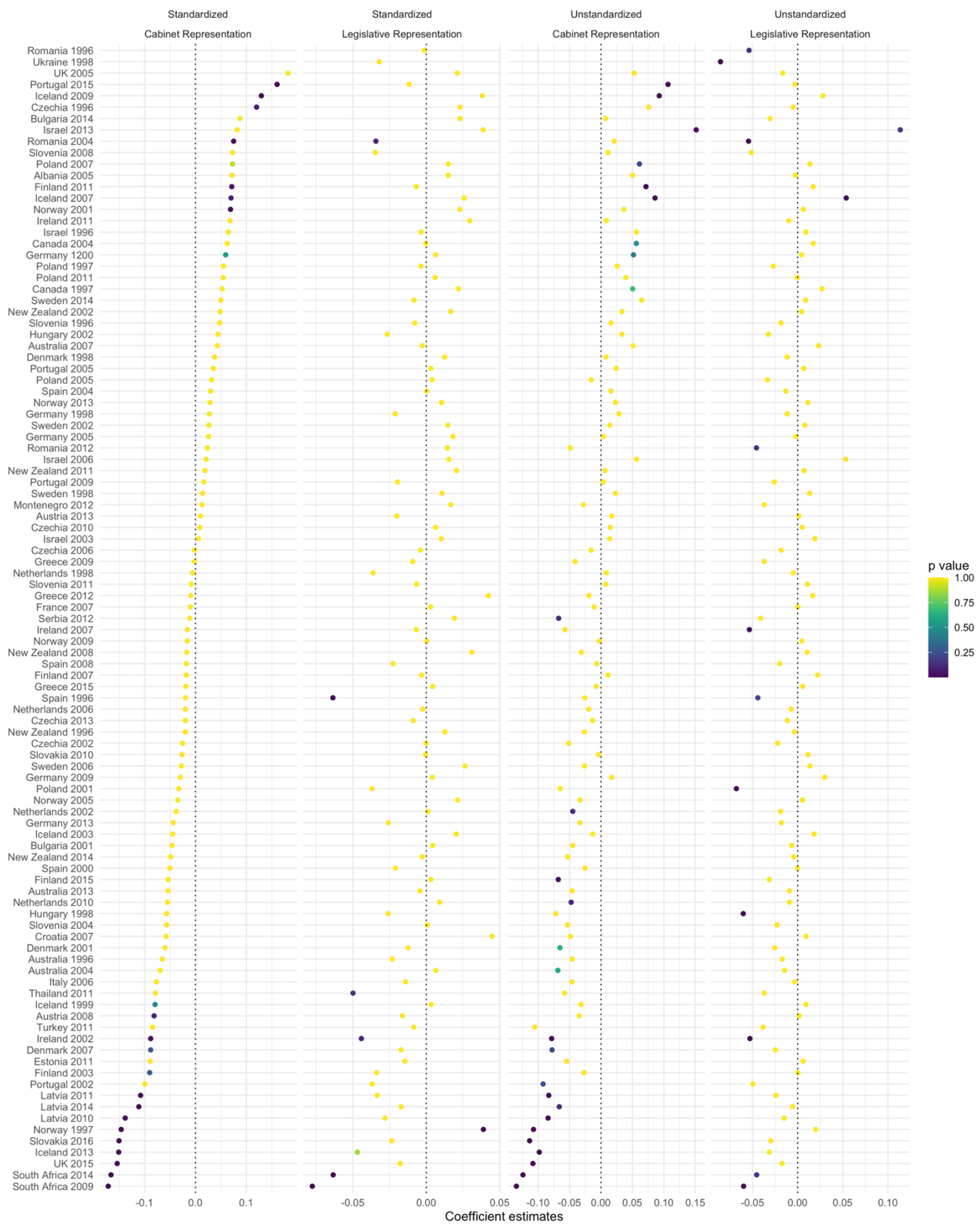


Coefficient estimates associated to the Left/Right variable.

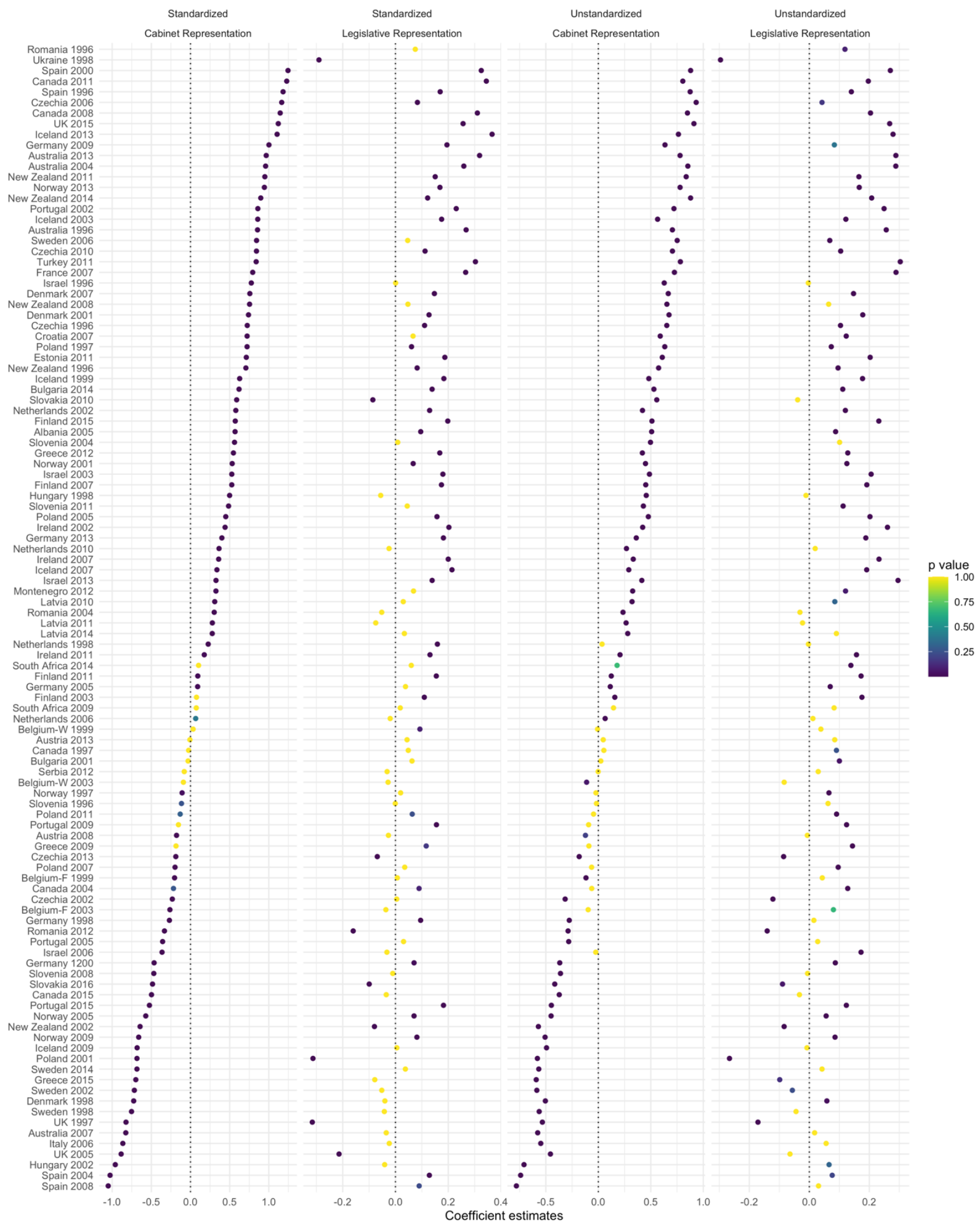


Coefficient estimates associated to the Extremism variable.

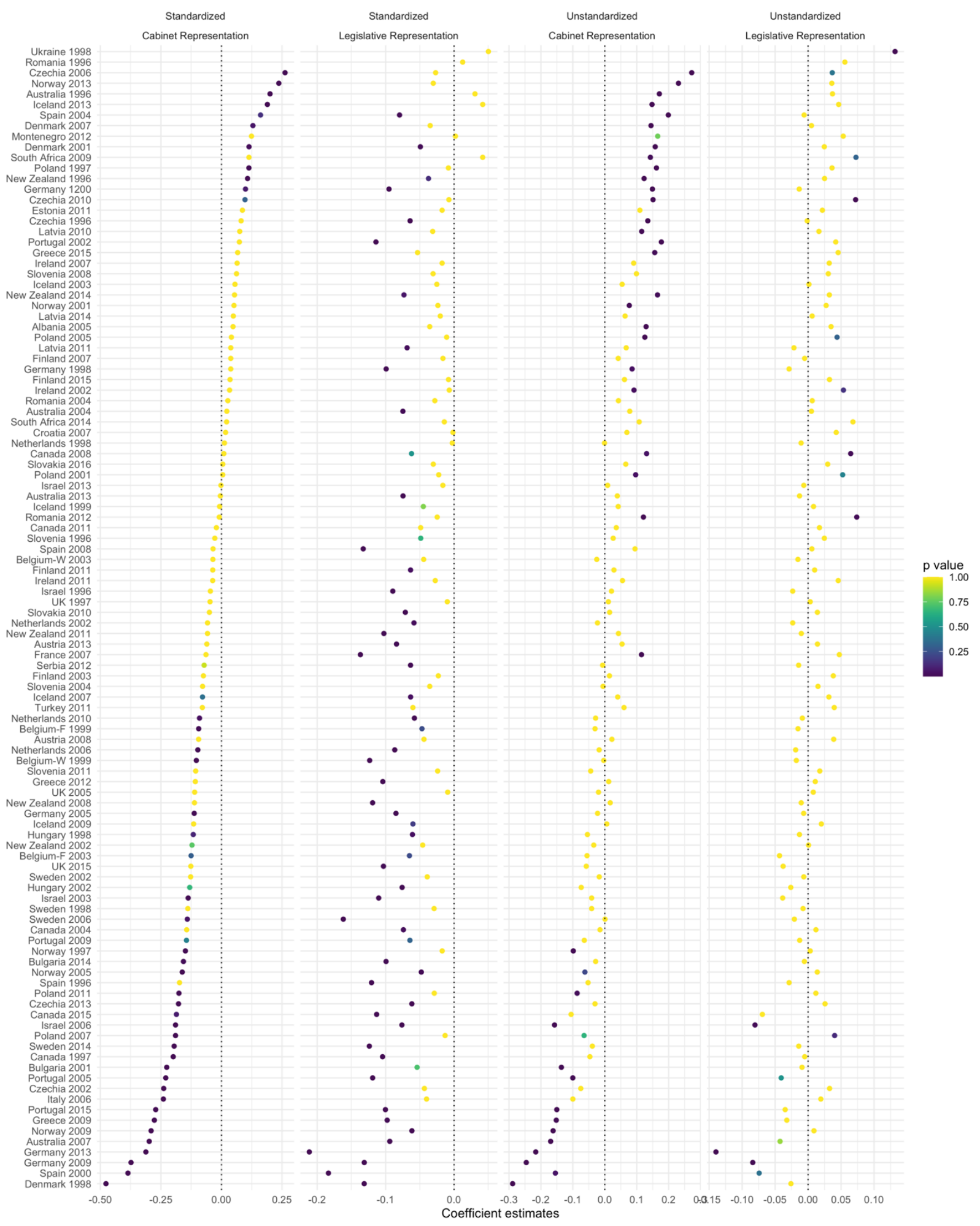




\section{Appendix E. Regression models with multiple imputations}

Multiple Imputation: Legislative representation.

\begin{tabular}{cccccccc}
\hline & Age & Education & Gender & Income & Rural & Left/Right & Extremism \\
\hline & 0.001 & 0.008 & -0.003 & 0.022 & -0.004 & 0.071 & -0.055 \\
& $(0.007)$ & $(0.004)$ & $(0.001)$ & $(0.003)$ & $(0.002)$ & $(0.013)$ & $(0.004)$ \\
\hline$N$ & 174420 & 172097 & 175475 & 139196 & 150836 & 139986 & 139986 \\
\hline
\end{tabular}

Note: All models include election fixed effects (not shown). Standard errors are robust and clustered by election (shown in parentheses). Missing party ratings were imputed five times.

Multiple Imputation: Cabinet representation.

\begin{tabular}{cccccccc}
\hline & Age & Education & Gender & Income & Rural & Left/Right & Extremism \\
\hline & 0.008 & 0.007 & -0.005 & 0.043 & -0.012 & 0.195 & -0.052 \\
& $(0.018)$ & $(0.010)$ & $(0.004)$ & $(0.009)$ & $(0.007)$ & $(0.060)$ & $(0.014)$ \\
\hline$N$ & 172170 & 169849 & 173224 & 137114 & 148588 & 138574 & 138574 \\
\hline
\end{tabular}

Note: All models include election fixed effects (not shown). Standard errors are robust and clustered by election (shown in parentheses). Missing party ratings were imputed five times.

\section{Multiple Imputation: Legislative representation (unstandardized).}

\begin{tabular}{cccccccc}
\hline & Age & Education & Gender & Income & Rural & Left/Right & Extremism \\
\hline & 0.014 & -0.004 & 0.007 & 0.012 & -0.010 & 0.084 & 0.007 \\
& $(0.007)$ & $(0.005)$ & $(0.001)$ & $(0.003)$ & $(0.003)$ & $(0.012)$ & $(0.004)$ \\
\hline$N$ & 179141 & 176797 & 180257 & 142491 & 155153 & 142885 & 142885 \\
\hline
\end{tabular}

Note: All models include election fixed effects (not shown). Standard errors are robust and clustered by election (shown in parentheses). Missing party ratings were imputed five times.

Multiple Imputation: Cabinet representation (unstandardized).

\begin{tabular}{cccccccc}
\hline & Age & Education & Gender & Income & Rural & Left/Right & Extremism \\
\hline & 0.026 & -0.006 & 0.007 & 0.026 & -0.014 & 0.185 & 0.021 \\
& $(0.014)$ & $(0.008)$ & $(0.002)$ & $(0.007)$ & $(0.005)$ & $(0.049)$ & $(0.011)$ \\
\hline$N$ & 176820 & 174478 & 177935 & 140344 & 152830 & 141436 & 141436 \\
\hline
\end{tabular}

Note: All models include election fixed effects (not shown). Standard errors are robust and clustered by election (shown in parentheses). Missing party ratings were imputed five times. 


\section{Appendix F. Mean representation scores and standard deviations for each election}

\section{Mean representation (cabinet) scores and standard deviations for each election}

\begin{tabular}{|c|c|c|}
\hline Election & $\begin{array}{c}\text { Score } \\
\text { (cabinet) }\end{array}$ & $\begin{array}{c}\mathrm{Sd} . \\
\text { (cabinet) }\end{array}$ \\
\hline 1. Slovenia 2011 & 0.400 & 0.263 \\
\hline 2. Greece 2012 & 0.455 & 0.311 \\
\hline 3. Spain 1996 & 0.456 & 0.451 \\
\hline 4. Slovenia 1996 & 0.460 & 0.247 \\
\hline 5. Slovenia 2004 & 0.477 & 0.270 \\
\hline 6. Czech Republic 2010 & 0.478 & 0.319 \\
\hline 7. Latvia 2011 & 0.487 & 0.283 \\
\hline 8. Slovakia 2010 & 0.494 & 0.270 \\
\hline 9. Croatia 2007 & 0.498 & 0.356 \\
\hline 10. Italy 2006 & 0.503 & 0.352 \\
\hline 11. Czech Republic 2006 & 0.503 & 0.436 \\
\hline 12. Montenegro 2012 & 0.510 & 0.443 \\
\hline 13. Belgium (W) 2003 & 0.512 & 0.182 \\
\hline 14. Slovakia 2016 & 0.521 & 0.311 \\
\hline 15. Germany 2009 & 0.523 & 0.319 \\
\hline 16. Estonia 2011 & 0.523 & 0.351 \\
\hline 17. Latvia 2014 & 0.526 & 0.256 \\
\hline 18. Israel 1996 & 0.526 & 0.355 \\
\hline 19. Finland 2011 & 0.528 & 0.167 \\
\hline 20. Norway 1997 & 0.531 & 0.251 \\
\hline 21. Bulgaria 2014 & 0.533 & 0.334 \\
\hline 22. Finland 2015 & 0.540 & 0.236 \\
\hline 23. Israel 2006 & 0.540 & 0.269 \\
\hline 24. New Zealand 1996 & 0.542 & 0.304 \\
\hline 25. Slovenia 2008 & 0.549 & 0.301 \\
\hline 26. Iceland 2013 & 0.550 & 0.353 \\
\hline 27. Canada 2011 & 0.552 & 0.451 \\
\hline 28. Norway 2001 & 0.556 & 0.213 \\
\hline 29. Australia 2013 & 0.556 & 0.425 \\
\hline 30. Israel 2013 & 0.557 & 0.243 \\
\hline 31. Romania 2004 & 0.558 & 0.270 \\
\hline
\end{tabular}

\begin{tabular}{|c|c|c|}
\hline 32. Czech Republic 1996 & 0.559 & 0.307 \\
\hline 33. Iceland 2003 & 0.560 & 0.325 \\
\hline 34. Finland 2003 & 0.560 & 0.205 \\
\hline 35. United Kingdom 2005 & 0.562 & 0.459 \\
\hline 36. Portugal 2002 & 0.563 & 0.380 \\
\hline 37. Czech Republic 2003 & 0.565 & 0.230 \\
\hline 38. Norway 2013 & 0.566 & 0.295 \\
\hline 39. Netherlands 1998 & 0.568 & 0.209 \\
\hline 40. Finland 2007 & 0.568 & 0.228 \\
\hline 41. Portugal 2015 & 0.572 & 0.405 \\
\hline 42. United Kingdom 2015 & 0.575 & 0.429 \\
\hline 43. Poland 1997 & 0.576 & 0.346 \\
\hline 44. Netherlands 2002 & 0.580 & 0.219 \\
\hline 45. Israel 2003 & 0.581 & 0.281 \\
\hline 46. Hungary 2002 & 0.582 & 0.413 \\
\hline 47. Portugal 2009 & 0.583 & 0.421 \\
\hline 48. Australia 1996 & 0.589 & 0.388 \\
\hline 49. Denmark 2007 & 0.590 & 0.318 \\
\hline 50. Hungary 1998 & 0.592 & 0.290 \\
\hline 51. Sweden 2006 & 0.596 & 0.267 \\
\hline 52. Canada 2008 & 0.598 & 0.424 \\
\hline 53. Albania 2005 & 0.600 & 0.332 \\
\hline 54. Poland 2001 & 0.601 & 0.348 \\
\hline 55. Latvia 2010 & 0.609 & 0.277 \\
\hline 56. Germany 2005 & 0.613 & 0.195 \\
\hline 57. Iceland 1999 & 0.614 & 0.290 \\
\hline 58. Canada 2004 & 0.615 & 0.397 \\
\hline 59. Iceland 2009 & 0.616 & 0.298 \\
\hline 60. Serbia 2012 & 0.618 & 0.235 \\
\hline 61. Japan 1996 & 0.620 & 0.271 \\
\hline 62. Denmark 2001 & 0.621 & 0.297 \\
\hline 63. Canada 2015 & 0.623 & 0.389 \\
\hline
\end{tabular}




\begin{tabular}{|c|c|c|}
\hline 64. Austria 2008 & 0.624 & 0.267 \\
\hline 65. Australia 2007 & 0.625 & 0.425 \\
\hline 66. Australia 2004 & 0.628 & 0.382 \\
\hline 67. Poland 2011 & 0.630 & 0.325 \\
\hline 68. Thailand 2001 & 0.632 & 0.294 \\
\hline 69. Denmark 1998 & 0.634 & 0.353 \\
\hline 70. Ireland 2007 & 0.634 & 0.326 \\
\hline 71. Belgium (F) 1999 & 0.635 & 0.219 \\
\hline 72. Belgium (F) 2003 & 0.638 & 0.282 \\
\hline 73. Norway 2005 & 0.639 & 0.211 \\
\hline 74. Austria 2013 & 0.640 & 0.247 \\
\hline 75. Netherlands 2010 & 0.644 & 0.240 \\
\hline 76. Germany 2002 & 0.644 & 0.308 \\
\hline 77. United Kingdom 1997 & 0.645 & 0.427 \\
\hline 78. Netherlands 2006 & 0.647 & 0.187 \\
\hline 79. Sweden 1998 & 0.648 & 0.373 \\
\hline 80. Norway 2009 & 0.648 & 0.234 \\
\hline 81. Germany 2013 & 0.651 & 0.228 \\
\hline 82. Thailand 2011 & 0.651 & 0.406 \\
\hline 83. Belgium (W) 1999 & 0.660 & 0.197 \\
\hline 84. Greece 2015 & 0.661 & 0.383 \\
\hline 85. Spain 2000 & 0.664 & 0.425 \\
\hline 86. Turkey 2011 & 0.667 & 0.434 \\
\hline 87. Germany 1998 & 0.668 & 0.288 \\
\hline
\end{tabular}

\begin{tabular}{|c|c|c|}
\hline 88. Bulgaria 2001 & 0.668 & 0.274 \\
\hline 89. Sweden 2014 & 0.669 & 0.265 \\
\hline 90. New Zealand 2011 & 0.675 & 0.408 \\
\hline 91. Poland 2007 & 0.678 & 0.317 \\
\hline 92. Czech Republic 2002 & 0.679 & 0.260 \\
\hline 93. Portugal 2005 & 0.683 & 0.368 \\
\hline 94. Poland 2005 & 0.685 & 0.356 \\
\hline 95. Spain 2008 & 0.685 & 0.387 \\
\hline 96. New Zealand 2008 & 0.686 & 0.384 \\
\hline 97. New Zealand 2002 & 0.689 & 0.357 \\
\hline 98. Iceland 2007 & 0.691 & 0.213 \\
\hline 99. South Africa 2014 & 0.693 & 0.404 \\
\hline 100. Canada 1997 & 0.694 & 0.344 \\
\hline 101. Ireland 2002 & 0.696 & 0.336 \\
\hline 102. France 2007 & 0.696 & 0.322 \\
\hline 103. New Zealand 2014 & 0.697 & 0.390 \\
\hline 104. Romania 2012 & 0.705 & 0.333 \\
\hline 105. Ireland 2011 & 0.709 & 0.267 \\
\hline 106. Greece 2009 & 0.709 & 0.354 \\
\hline 107. Spain 2004 & 0.714 & 0.374 \\
\hline 108. Sweden 2002 & 0.714 & 0.336 \\
\hline 109. South Africa 2009 & 0.726 & 0.398 \\
\hline
\end{tabular}


2. Mean representation (legislature) scores and standard deviations for each election

\begin{tabular}{|c|c|c|}
\hline Election & $\begin{array}{c}\text { Score } \\
\text { (Legislative) }\end{array}$ & $\begin{array}{c}\text { Sd. } \\
\text { (Legislative) }\end{array}$ \\
\hline 1. Bulgaria 2014 & 0.409 & 0.160 \\
\hline 2. Greece 2012 & 0.440 & 0.184 \\
\hline 3. Montenegro 2012 & 0.452 & 0.182 \\
\hline 4. Slovakia 2016 & 0.459 & 0.162 \\
\hline 5. Slovenia 2011 & 0.461 & 0.167 \\
\hline 6. Czech Republic 2010 & 0.464 & 0.139 \\
\hline 7. Czech Republic 2013 & 0.473 & 0.132 \\
\hline 8. Latvia 2014 & 0.475 & 0.138 \\
\hline 9. Slovenia 2004 & 0.484 & 0.170 \\
\hline 10. Czech Republic 2006 & 0.484 & 0.150 \\
\hline 11. Italy 2006 & 0.488 & 0.149 \\
\hline 12. Israel 2006 & 0.492 & 0.143 \\
\hline 13. United Kingdom 2005 & 0.493 & 0.185 \\
\hline 14. Slovenia 1996 & 0.495 & 0.153 \\
\hline 15. Croatia 2007 & 0.495 & 0.186 \\
\hline 16. Slovenia 2008 & 0.499 & 0.195 \\
\hline 17. Portugal 2009 & 0.501 & 0.186 \\
\hline 18. Portugal 2015 & 0.505 & 0.181 \\
\hline 19. Latvia 2011 & 0.505 & 0.155 \\
\hline 20. Estonia 2011 & 0.505 & 0.156 \\
\hline 21. Israel 2003 & 0.507 & 0.155 \\
\hline 22. Poland 1997 & 0.509 & 0.158 \\
\hline 23. Czech Republic 1996 & 0.509 & 0.133 \\
\hline 24. Ukraine 1998 & 0.510 & 0.206 \\
\hline 25. Canada 2004 & 0.510 & 0.168 \\
\hline 26. Finland 2015 & 0.511 & 0.151 \\
\hline 27. Albania 2005 & 0.512 & 0.150 \\
\hline 28. Germany 2009 & 0.513 & 0.149 \\
\hline 29. Poland 2011 & 0.515 & 0.164 \\
\hline 30. Austria 2008 & 0.515 & 0.146 \\
\hline 31. Finland 2011 & 0.515 & 0.137 \\
\hline 32. Israel 2013 & 0.516 & 0.154 \\
\hline
\end{tabular}

\begin{tabular}{|c|c|c|}
\hline 33. Turkey 2011 & 0.518 & 0.216 \\
\hline 34. Norway 2001 & 0.518 & 0.115 \\
\hline 35. Finland 2003 & 0.520 & 0.151 \\
\hline 36. Czech Republic 2002 & 0.521 & 0.124 \\
\hline 37. Spain 1996 & 0.522 & 0.181 \\
\hline 38. Iceland 2013 & 0.524 & 0.166 \\
\hline 39. Austria 2013 & 0.525 & 0.147 \\
\hline 40. Canada 2008 & 0.526 & 0.182 \\
\hline 41. Sweden 1998 & 0.526 & 0.129 \\
\hline 42. Serbia 2012 & 0.528 & 0.154 \\
\hline 43. Greece 2015 & 0.528 & 0.184 \\
\hline 44. Belgium (F) 2003 & 0.532 & 0.144 \\
\hline 45. Romania 2004 & 0.533 & 0.150 \\
\hline 46. Iceland 2003 & 0.534 & 0.135 \\
\hline 47. Latvia 2010 & 0.534 & 0.161 \\
\hline 48. Poland 2007 & 0.536 & 0.139 \\
\hline 49. Bulgaria 2001 & 0.536 & 0.154 \\
\hline 50. Canada 1997 & 0.537 & 0.169 \\
\hline 51. Poland 2005 & 0.538 & 0.172 \\
\hline 52. Finland 2007 & 0.539 & 0.157 \\
\hline 53. Poland 2001 & 0.542 & 0.209 \\
\hline 54. Belgium (F) 1999 & 0.543 & 0.136 \\
\hline 55. Spain 2004 & 0.546 & 0.153 \\
\hline 56. Iceland 2009 & 0.547 & 0.147 \\
\hline 57. Israel 1996 & 0.547 & 0.141 \\
\hline 58. United Kingdom 2015 & 0.548 & 0.219 \\
\hline 59. Romania 1996 & 0.548 & 0.152 \\
\hline 60. Australia 2013 & 0.549 & 0.197 \\
\hline 61. Belgium (W) 2003 & 0.550 & 0.235 \\
\hline 62. New Zealand 2002 & 0.551 & 0.152 \\
\hline 63. Slovakia 2010 & 0.552 & 0.143 \\
\hline 64. New Zealand 1996 & 0.553 & 0.155 \\
\hline 65. Netherlands 2002 & 0.553 & 0.129 \\
\hline 66. Hungary 1998 & 0.553 & 0.152 \\
\hline
\end{tabular}




\begin{tabular}{|c|c|c|}
\hline 67. United Kingdom 1997 & 0.554 & 0.215 \\
\hline 68. Norway 1997 & 0.554 & 0.135 \\
\hline 69. Canada 2011 & 0.554 & 0.222 \\
\hline 70. Spain 2008 & 0.555 & 0.178 \\
\hline 71. Denmark 1998 & 0.557 & 0.140 \\
\hline 72. Australia 1996 & 0.558 & 0.195 \\
\hline 73. Sweden 2014 & 0.559 & 0.106 \\
\hline 74. Denmark 2007 & 0.559 & 0.125 \\
\hline 75. Thailand 2011 & 0.562 & 0.168 \\
\hline 76. Sweden 2002 & 0.563 & 0.125 \\
\hline 77. Denmark 2001 & 0.564 & 0.124 \\
\hline 78. Netherlands 1998 & 0.567 & 0.155 \\
\hline 79. Netherlands 2010 & 0.568 & 0.115 \\
\hline 80. Hungary 2002 & 0.570 & 0.150 \\
\hline 81. Portugal 2005 & 0.570 & 0.190 \\
\hline 82. Australia 2007 & 0.573 & 0.178 \\
\hline 83. Romania 2012 & 0.574 & 0.210 \\
\hline 84. Canada 2015 & 0.575 & 0.214 \\
\hline 85. Germany 2005 & 0.576 & 0.153 \\
\hline 86. Portugal 2002 & 0.580 & 0.207 \\
\hline 87. Iceland 1999 & 0.582 & 0.151 \\
\hline 88. Norway 2005 & 0.582 & 0.116 \\
\hline 89. Greece 2009 & 0.586 & 0.202 \\
\hline 90. Germany 1998 & 0.591 & 0.160 \\
\hline 91. Norway 2009 & 0.595 & 0.123 \\
\hline 92. Spain 2000 & 0.595 & 0.213 \\
\hline 93. Norway 2013 & 0.598 & 0.129 \\
\hline 94. South Africa 2014 & 0.598 & 0.222 \\
\hline 95. New Zealand 2011 & 0.599 & 0.160 \\
\hline 96. Netherlands 2006 & 0.601 & 0.132 \\
\hline 97. Ireland 2002 & 0.601 & 0.194 \\
\hline 98. Germany 2002 & 0.602 & 0.155 \\
\hline 99. New Zealand 2014 & 0.603 & 0.172 \\
\hline 100. Sweden 2006 & 0.604 & 0.140 \\
\hline 101. Thailand 2001 & 0.604 & 0.187 \\
\hline
\end{tabular}

\begin{tabular}{|l|l|l|}
\hline 102. Ireland 2007 & 0.608 & 0.205 \\
\hline 103. Iceland 2007 & 0.609 & 0.149 \\
\hline 104. New Zealand 2008 & 0.612 & 0.160 \\
\hline 105. South Africa 2009 & 0.617 & 0.236 \\
\hline 106. Japan 1996 & 0.618 & 0.220 \\
\hline 107. Australia 2004 & 0.619 & 0.198 \\
\hline 108. Ireland 2011 & 0.621 & 0.195 \\
\hline 109. Germany 2013 & 0.621 & 0.181 \\
\hline 110. Belgium (W) 1999 & 0.627 & 0.186 \\
\hline 111. France 2007 & 0.668 & 0.194 \\
\hline
\end{tabular}


Appendix G. Scatter plots of the relationship between the disproportionality index and district magnitude and mean representation score (legislature and cabinet)

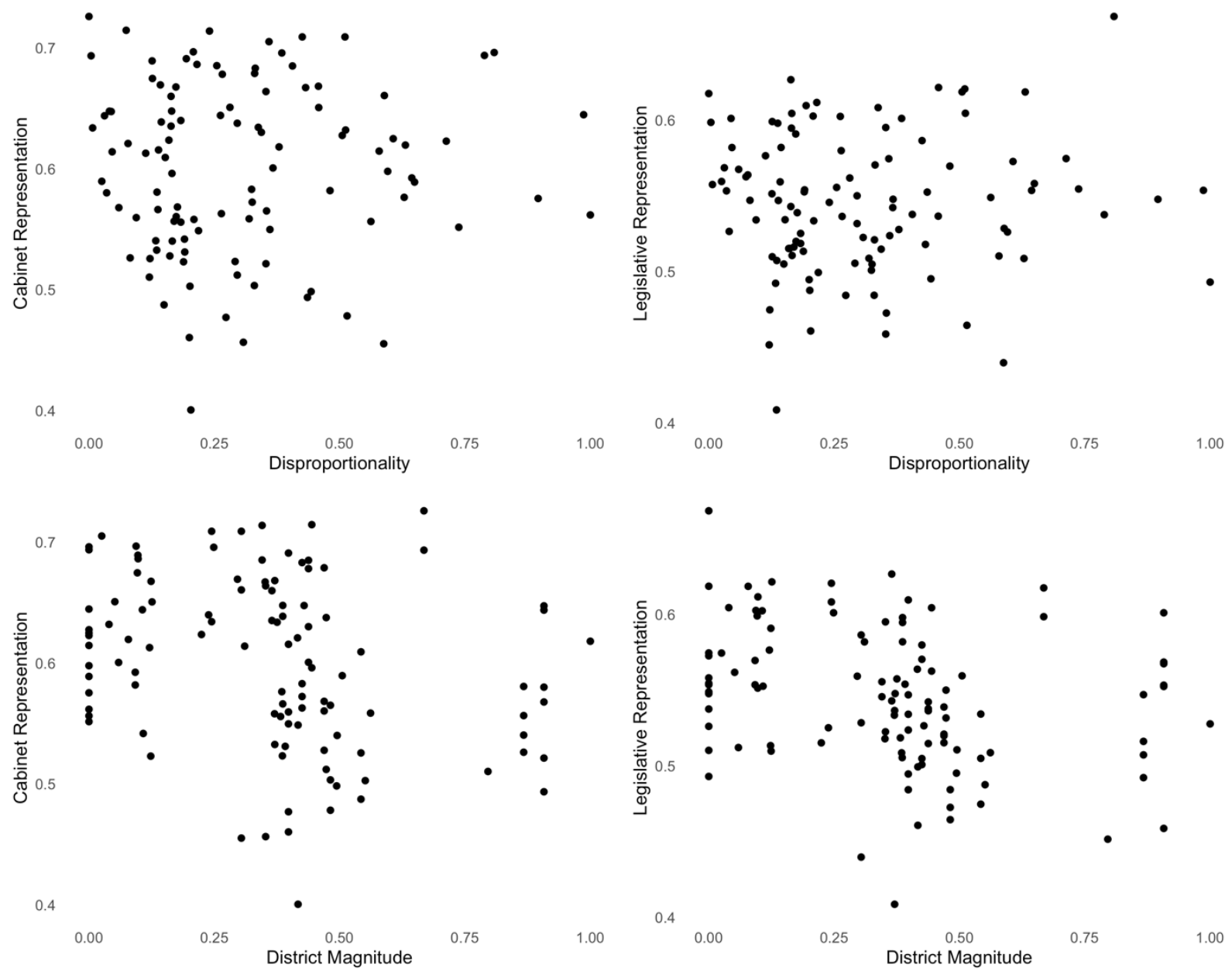


Appendix H. Scatter plots of the relationship between the disproportionality index and district magnitude and the standard deviation of the representation scores (legislature and cabinet)

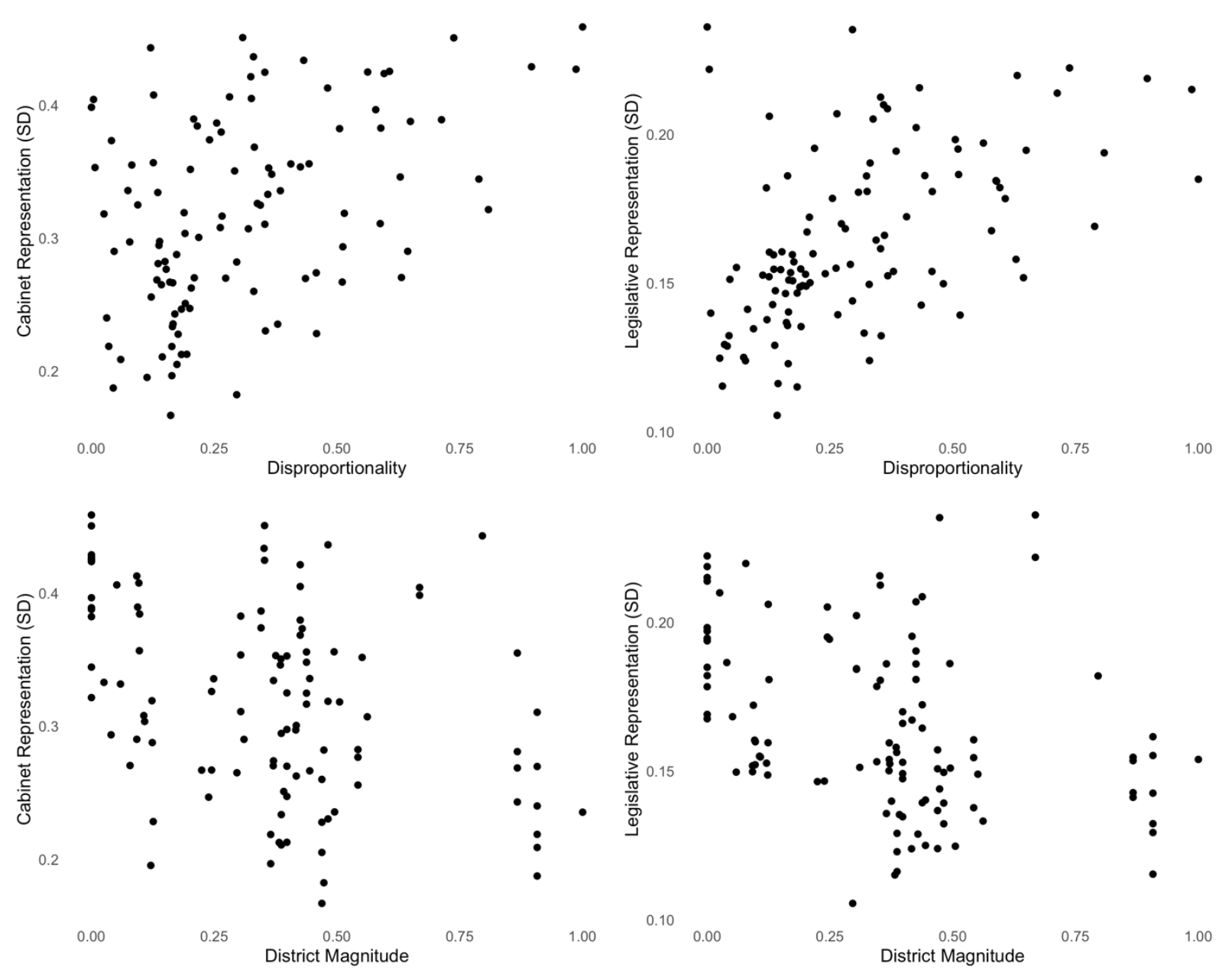

